\title{
Hypothyroidism-Induced Nonalcoholic Fatty Liver Disease (HIN): Mechanisms and Emerging Therapeutic Options
}

\author{
Daniela Maria Tanase ${ }^{1,2}$, Evelina Maria Gosav 1,2,*,+(D), Ecaterina Neculae ${ }^{3,4,+}$, \\ Claudia Florida Costea ${ }^{5,6}$, Manuela Ciocoiu ${ }^{7}$, Loredana Liliana Hurjui ${ }^{8,9}$, \\ Claudia Cristina Tarniceriu ${ }^{10,11,+}$ and Mariana Floria ${ }^{1,12}$ (D) \\ 1 Department of Internal Medicine, “Grigore T. Popa” University of Medicine and Pharmacy, 700111 Iasi, \\ Romania; tanasedm@gmail.com (D.M.T.); floria.mariana@umfiasi.ro (M.F.) \\ 2 Internal Medicine Clinic, “Sf. Spiridon" County Clinical Emergency Hospital Iasi, 700115 Iasi, Romania \\ 3 Department of Gastroenterology, "Grigore T. Popa” University of Medicine and Pharmacy, 700115 Iasi, \\ Romania; ecaterina.neculae91@gmail.com \\ 4 Institute of Gastroenterology and Hepatology, "Sf. Spiridon" County Clinical Emergency Hospital Iasi, \\ 700111 Iasi, Romania \\ 5 Department of Ophthalmology, “Grigore T. Popa” University of Medicine and Pharmacy, 700115 Iasi, \\ Romania; claudia.costea@umfiasi.ro \\ 6 2nd Ophthalmology Clinic, "Prof. Dr. Nicolae Oblu” Emergency Clinical Hospital, 700115 Iași, Romania \\ 7 Department of Pathophysiology, Faculty of Medicine, "Grigore T. Popa” University of Medicine and \\ Pharmacy, 700115 Iasi, Romania; manuela.ciocoiu@umfiasi.ro \\ 8 Department of Morpho-Functional Sciences II, Physiology Discipline, “Grigore T. Popa” University of \\ Medicine and Pharmacy, 700115 Iasi, Romania; loredana.hurjui@umfiasi.ro \\ 9 Hematology Laboratory, "Sf. Spiridon" County Clinical Emergency Hospital, 700111 Iasi, Romania \\ 10 Department of Morpho-Functional Sciences I, Discipline of Anatomy, “Grigore T. Popa" University of \\ Medicine and Pharmacy, 700115 Iasi, Romania; claudia.tarniceriu@umfiasi.ro \\ 11 Hematology Clinic, "Sf. Spiridon" County Clinical Emergency Hospital, 700111 Iasi, Romania \\ 12 Internal Medicine Clinic, Emergency Military Clinical Hospital, 700483 Iasi, Romania \\ * Correspondence: dr.evelinagosav@gmail.com \\ + These authors contributed equally to this work.
}

Received: 31 July 2020; Accepted: 16 August 2020; Published: 18 August 2020

\begin{abstract}
Nonalcoholic fatty liver disease (NAFLD) is an emerging worldwide problem and its association with other metabolic pathologies has been one of the main research topics in the last decade. The aim of this review article is to provide an up-to-date correlation between hypothyroidism and NAFLD. We followed evidence regarding epidemiological impact, immunopathogenesis, thyroid hormone-liver axis, lipid and cholesterol metabolism, insulin resistance, oxidative stress, and inflammation. After evaluating the influence of thyroid hormone imbalance on liver structure and function, the latest studies have focused on developing new therapeutic strategies. Thyroid hormones (THs) along with their metabolites and thyroid hormone receptor $\beta$ (THR- $\beta$ ) agonist are the main therapeutic targets. Other liver specific analogs and alternative treatments have been tested in the last few years as potential NAFLD therapy. Finally, we concluded that further research is necessary as well as the need for an extensive evaluation of thyroid function in NAFLD/NASH patients, aiming for better management and outcome.
\end{abstract}

Keywords: nonalcoholic fatty liver disease (NAFLD); hypothyroidism; thyromimetics 


\section{Introduction}

Nonalcoholic fatty liver disease is the most frequent cause of chronic liver disease that affects millions of people worldwide [1,2]. Genetics, obesity, unhealthy lifestyle, and other metabolic risk factors could be responsible for the burgeoning evolution, increased prevalence, and incidence of NAFLD. This multifactorial and dynamic entity is defined by hepatic fat accumulation in the absence of hereditary and autoimmune conditions, drug-induced liver injury, alcohol consumption, or viral etiology [3,4]. NAFLD encompasses a wide range of liver conditions from simple steatosis/nonalcoholic fatty liver (NAFL) to nonalcoholic steatohepatitis (NASH), cirrhosis, and finally, hepatocellular carcinoma (HCC) [5]. Considering the common and possible evolution to NASH and cirrhosis, NAFLD has become one of the main causes of liver transplantation [6]. It is characterized by comorbid manifestations that extend beyond the liver and in an all-cause mortality/morbidity relationship, plenty of evidence highlights its association with metabolic disorders, type 2 diabetes mellitus (T2DM), chronic kidney disease (CKD), gallstone disease, cardiovascular, and endocrine illnesses (hypothyroidism, polycystic ovarian syndrome, or hypogonadism) [7-12]. As NAFLD is considered the cause or the consequence of metabolic syndrome, which is reflected primarily by raised visceral adiposity that promotes insulin resistance (IR), glucose intolerance, and overall a lipotoxic status, it is possible that its metabolic substrates may share pathogenic factors with hypothyroidism [13-16]. More than that, below range serum concentration of thyroid hormones (THs) has been linked to the development of metabolic syndrome, obesity, atrial fibrillation, and cancer onsets [17-20].

Hypothyroidism continues to remain a global problem with increased incidence among the adult and newborn population, and illustrates decreased metabolic rate determined by hyposecretion of THs from the thyroid gland [21]. Studies have shown that patients with over ten years of thyroid dysfunction have significantly higher chances of developing HCC [22], and that in subjects with NASH and chronic hepatitis B infection, a higher thyroid dysfunction was found compared to that of the control group [23]. Hence, hypothyroidism may probably be the best example of NAFLD secondary to an endocrine disorder. Notably, hypothyroidism-induced NAFLD (HIN) was acknowledged recently as a distinct disease entity [24]. More than that, treatment of hormonal deficiency has been shown to improve liver condition [25] and that hyperthyroidism may improve NASH [26], which raises the interesting question of whether hormone replacing therapy could be beneficial in NAFLD.

In this review, we discuss the growing epidemiological evidence associating these two diseases, the key factors behind immunopathogenesis, how hormone replacing therapy impacts liver function, which of the newest therapeutic targets are being researched, and mostly, we hope to raise awareness among clinicians about the possible liver impairment in endocrine pathologies as well as the need for the evaluation of thyroid function in NAFLD/NASH patients for better management and outcome [24].

\section{Definitions and Epidemiological Discoveries}

For many years, scientific research has been conducted in order to demonstrate an association and/or a causal relationship between hypothyroidism and NAFLD. Before we briefly discuss the epidemiological grounds of HIN, we must mention the clinical and biochemical definition of hypothyroidism and NAFLD.

Hypothyroidism is characterized by high plasma thyroid-stimulating hormone (TSH) in concurrence with either low plasma TH levels and a free thyroxine (fT4) that is within the reference range without obvious clinical symptoms (subclinical hypothyroidism) or with low fT4 accompanied by obvious clinical symptoms (overt hypothyroidism). Related to the cause, hypothyroidism is primarily due to thyroid dysfunction and secondary to the flawed hypothalamic-pituitary axis or to different disorders $[27,28]$. Current guidelines recommend that for subclinical hypothyroidism diagnosis, the cut-off level of TSH used should be between 4.0 and $4.5 \mathrm{mIU} / 1$. Some evidence has shown that the upper normal limit of TSH interpreted by laboratory tests depends on many variables and conditions [29]. On the other hand, hepatic steatosis is defined by liver fat accumulation over $5 \%$ of hepatocytes with the lack of other secondary causes or by over $5.6 \%$ of proton density fat detected by magnetic resonance 
imaging (MRI)/spectroscopy [4,5]. Nonetheless, the golden standard for diagnosis remains the invasive liver biopsy, despite its potential severe side effects $[4,30]$. These definitions are very relevant to our later debate and might explain the confuting results found in studies that have investigated the entangled associations between hypothyroidism and NAFLD.

In the last years, substantial growth of inflammatory and endocrinological diseases has also been observed in a younger population. Hyperthyrotropinemia is defined as normal T4 levels accompanied by abnormal transient rise of TSH levels after the first two days of life, which goes back to normal after two or three weeks [31]. The intriguing transient hyperthyrotropinemia found in many neonatal children could be a consequence, or perhaps could play an independent part in the later adult development of obesity, IR, and dyslipidemia [32]. The congenital hypothyroid pediatric population displayed a positive relationship between TSH and lipid values and a higher prevalence of NAFLD [33]. Data showed that children with obesity and dysregulation of TH levels have a higher risk of developing hepatic steatosis [34]. In euthyroid overweight and obese children, researchers found a prevalence of NAFLD of almost $30 \%$ and that NAFLD individuals had significantly higher TSH levels than non-steatosis subjects, while T3 and T4 levels had similar values in both groups [35]. Moderate thyroid dysfunction could contribute to an unfavorable metabolic status in an overweight and obese younger population, which underlines the possible role of subclinical hypothyroidism as a predictive marker of metabolic dysfunction and open new views about possible metabolic therapeutic targets that could benefit both disorders [36].

Concerning the evaluation of HIN among the adult population, substantial evidence has emerged over the last two decades and includes cross-sectional [37-49], case-control [37,43,50-54], cohort [55,56], retrospective analysis [57], and meta-analyses studies [57-60]. Among these, some found a higher prevalence of NALFD among hypothyroid patients (subclinical and overt hypothyroidism) in a dose-dependent manner [37,39,42,43,45,50,52,53,59-61], a linear association between TSH levels and increased risk of NALD/NASH $[35,40,44,45,61]$, and a correlation between higher fT3 $[46,56,59]$ or low fT4 $[41,51,56,59,62]$ plasma levels with raised risk of liver steatosis. Additionally, fT3/fT4 ratio, insulin resistance, waist circumference, and hypertriglyceridemia seem to be independent risk factors for NAFLD in hypothyroid or euthyroid patients [48]. Subclinical and/or overt hypothyroidism were associated with an increased risk of liver fibrosis $[49,55]$ and low fT3 values were associated with increased liver stiffness and increased fibrosis score [57]. For the diagnosis of NAFLD, numerous studies have performed ultrasonography and thyroid dysfunction definition studies have used laboratory parameters, or/and history/self-reported of hypothyroidism on hormone replacement therapy. The majority of these studies were performed on the Asian continent. These results occurred after adjustments such as age, sex, smoking, body mass index, dyslipidemia, diabetes, hypertension, or for other cardio-metabolic risk factors were made. In the meta-analyses aforementioned, the authors adjusted multiple clinical and demographics variables. Guo et al. [60] documented that NAFLD individuals had higher TSH levels, while in Mantovani et al. [61], patients with primary hypothyroidism had a 2.7-fold higher risk of developing NAFLD/NASH. Rather, caution when reading the results of such studies, assumptions and hasty conclusions should not be made. However, the amount of evidence suggests that there is a significant association between THs derangement and NAFLD development, and strong consideration for such a possible disease connection should be made, especially if the patients suffer from obesity [63].

There are a few studies that did not discover any significant connection between hypothyroidism and liver steatosis $[62,64-71]$. Nonetheless, they pointed out that in women with NAFLD plasma, TSH concentrations were significantly higher than the controls [62], low fT4 levels were associated with liver steatosis [64], THs abnormalities could be due to sick euthyroid syndrome [65], hypothyroidism was associated with higher TG levels and a greater prevalence of obesity, and higher alteration of AST correlated with elevated TSH levels [71].

These inconclusive results emphasize the differences and limitations of studies represented by the study design, size, population demographics, environmental factors, the applied adjustments, 
definition, and diagnostic methods for NAFLD and hypothyroidism. Polymorphic variants [72], gender [17,73], and heterogeneity [74] are also variable factors that participate in HIN development.

As seen, there is no clear evidence that may portray a cause-effect relationship between hypothyroidism and NAFLD, and the conflicting reports noted in the literature raises questions regarding this hypothesis. Further larger trials are needed to explore HIN, the molecular mechanism behind it, and maybe pave new roads regarding the use of thyromimetics in NAFLD.

\section{Immunopathogenesis}

Even if quondam investigations have thoroughly tried to describe the pathophysiology of hypothyroidism-induced NAFLD, the fundamental matrix behind this distinct entity is far from entirely known [24]. We know that low thyroid levels are commonly associated with hypometabolism. This state is defined by weight gain, reduced resting energy expenditure, reduced gluconeogenesis, and reduced lipolysis. THs dysfunction can instigate obesity, deficient lipid metabolism, and IR, which are elements of the metabolic syndrome also encountered in NAFLD [75-77]. Perhaps via the three-known mechanisms of NAFLD (hepatic lipid accumulation, inflammatory status accompanied by oxidative stress, and subsequently defective liver repair and regenerative response), hypothyroidism may directly or indirectly contribute to NAFLD. Thus, researchers have studied the profound interaction and signaling between THs, thyroid hormone receptors (TRs), and liver function [78,79].

\subsection{Thyroid Hormone-Liver Axis}

The thyroid gland is a pivotal endocrine organ responsible for thermogenesis, adipogenesis, fat distribution, energy, lipid, protein, carbohydrate, and cell metabolism [80]. The THs 3,5,3'-triiodothyronine (T3) and 3,5,3',5'-tetraiodothyronine/thyroxine (T4) are important keys for tissue repair as they mediate cellular differentiation and interfere with cell-signaling mechanisms via protein-protein synergy through collaboration with nuclear receptors or binding to other proteins $[81,82]$. Production of THs from the thyroid gland is modulated centrally by thyrotrophs of the anterior pituitary that produce TSH, which in turn is regulated by the hypothalamus. The hypothalamus secretes the thyrotropin-releasing hormone (TRH). The secreted THs are then transported on cell membranes and their peripheral signaling is expressed in the adipose and hepatic tissue $[83,84]$. The TRs combine with another nuclear receptor and form the retinoid X receptor (RXR), which binds to thyroid hormone response elements (TREs) in regulatory portions of the target genes. The cytoplasmatic TRs regulate the noncanonical THs signaling, while the canonical signaling is considered the main mediator that controls, via TR $\beta$, the hypothalamic-pituitary-thyroid axis. The TRs also control the actions of T3 [85-87]. There are two key thyroid receptor isoforms represented by the thyroid hormone receptor $\alpha 1$ and $\beta 1$ (THR- $\alpha$ and THR- $\beta$ ). THR- $\alpha$ isoforms are ubiquitously expressed, but mainly found in the cardiovascular system, white adipose tissue (WAT), and in bone structures, whereas THR- $\beta$ is mostly expressed in the hepatic organ and cardiac ventricle [85,88]. In NASH patients who underwent bariatric surgery, researchers found that THR- $\beta$ messenger RNA (mRNA) negatively correlated with steatosis activity, implying that during disease development, there is a progressive resistance to THs. Resistance to TH is defined as a syndrome in which tissues have diminished sensitivity to TH [88]. THs exert different central and peripheral functions [89] and are influential modulators in liver regeneration as they can crosstalk with growth factors and integrins to regulate physio-pathological responses. THs mediate the number and function of different peroxisomal enzymes, and can regulate mitochondrial biogenesis and function in the hepatic cells (HCs) [90,91]. These particular properties of THs in the liver may explain the involvement of THs in liver cancer onset [92].

Tissue THs activity is controlled by deiodinases (D1, D2, and D3). Deiodinases are peroxidase seleno-dependent enzymes that are capable of activation or deactivation of THs in the peripheral tissues. Intrahepatic TH activity and homeostasis is regulated by serum TH levels and also by liver deiodinases [93]. While substrate T4 is converted into active hormone T3 by D1, D3 transforms T4 and T3 into inactive products, rT3, and diiodothyronine (T2), respectively. More than that, via D1, rT3 is 
catalyzed to T2 [94]. In healthy liver, hepatocytes express high levels of D1 while stromal cells express low D3 levels. Midst injury, a loss of D1 in hepatocytes is identified, while D3 expression in stromal cells increases, especially in fibrogenic myofibroblast. Intrahepatic hypothyroidism limits exposure to T3, which has an important role in cellular differentiation, is a greater regulator of metabolic systems than T4, and has oncosuppressor properties [95]. T3 expression is restrained during early phases of embryogenesis through D3 raised levels. After birth, D1 and D2 levels increase while D3 levels decrease, therefore T3 is granted the possibility to incite cellular differentiation and tissue maturation [96,97]. Evidence shows that after partial hepatectomy, myocardial infarction or in injured skeletal muscle, the expression of D3 is upregulated [98]. Additionally, in many chronic diseases, the hepatic D1 activity is reduced, whereas D2 along with TRs, uncoupling proteins, and beta-adrenergic receptors contribute to the development of obesity [99]. As a secondary mechanism for fat deposition, there is a raised conversion of T4 to T3 via enhanced deiodinase activity [100].

In liver injury, the expression of the nuclear TRs in HSCs is repressed, hence the main hormone receptor becomes THR- $\alpha$, which starts an elaborate fibrogenic response and higher contractility. Detection in vitro of the HSC activation revealed that T3 may assist in the resolution of liver fibrosis in rats by mediating transforming growth factor-beta (TGF- $\beta$ )-induced collagen I gene expression [101]. Injury-activated HSCs are crucial components for liver regeneration as they are major sources of myofibroblasts. These stromal cells promote mediators of angiogenesis, chemokines, and diverse growth factors [102]. As they activate, HSCs induce mutual changes in D1 and D3 hepatic expression, especially in D3, which diminishes the active-THs accumulation. These mechanisms can cross-talk in their way to affect TH expression [103]. Putative evidence is needed to elucidate the exact mechanism behind D1-D3 hepatic repair and the control behind TH homeostasis. The authors believe that D3 could represent a new therapeutic target in hepatic injury and fibrosis, and that rt 3 could also be a novel biomarker [104]. This shows how intricate the relationship between the liver, THs, and TRs is and how different their influence is on each other, depending on the primary disorder.

\subsection{Lipid and Cholesterol Metabolism}

Normally, there is an equilibrium between hepatic lipid synthesis and catabolism; however, an abundance of dietary intake leads to excess of plasma glucose, which enhances glycolysis and lipogenesis, with a subsequent rise in intracellular free fatty acids (FFAs) that can debilitate TR activity [105]. When energy intake happens, ATP is formed from carbohydrate oxidation and glycogen stocks are restored in the skeletal muscle and liver. Glycogen could account for the major deposit source of hepatic energy. Even if the link between liver glycogen and hypothyroidism is still unclear [106], the data show that low TH plasma concentrations may alter glycogen accumulation by decreasing the fatty acid synthase (FAS) and acetyl-CoA carboxylase (ACC) activity [107].

In excess conditions, the carbohydrate is transformed into fatty acids (FAs) via "de novo lipogenesis" (DNL). Most of the hepatic lipid accumulation is represented by re-esterification of circulating FFAs, followed by DNL, and finally, by dietary fatty acids. FAs go through one of the three metabolic transformations: $\beta$-oxidation (hepatic desaturation and elongation), esterification, and accumulation as TG or transformation and secretion as lipoproteins. NAFLD subjects have high levels of diacylglycerols, triacylglycerols, and elevated saturated FAs composition. Triacylglycerol can accumulate as fat droplets, or can be added to very-low-density lipoprotein (VLDL) or help with cellular reparation [108,109]. It seems that the derivative 3,5-diiodothyronine can regulate the activity of hepatic lipases to raise lipid mobilization from fat droplets [110]. DNL, along with triacylglycerol synthesis, are steadily coordinated by hormones and various crucial enzymatic processes [111]. THs regulate lipogenesis by binding to the specific genes of TRs, which can then mediate the transport of FFAs into the liver cells with the help of protein transports like liver fatty acid binding proteins (L-FABPs), fatty acid transporter proteins (FATPs), and fatty acid translocase (FAT). In the hepatocytes via THR- $\beta$, THs can increase the mitochondrial oxidation of FAs, promote the intrahepatic lipolysis through lipophagy with subsequently decreased TG clearance and increased TG hepatic up-take [112]. Studies show that 
TH enhances the activity and recruitment of Zinc- $\alpha 2$-Glycoprotein in hepatic cells that help facilitate lipolysis [113]. Nonetheless, this lipidic surplus can lead to cellular stress, apoptosis, and consequent liver impairment. Hence, the biochemical panel of NAFLD/NASH patients often register elevated liver transaminase, low-density lipoproteins (LDL), cholesterol, and TG levels [114].

Studies noted that NAFLD subjects have a lower concentration of THs [92], that small elevated TSH levels are linked to higher risk and prevalence of metabolic syndrome [115], and that TSH can hasten the onset and progression of NAFLD/NASH [116]. A sufficient reduction of TH levels is enough to lower the response of adipose tissue to adrenergic signaling. In these conditions, insufficient adrenergic stimulation of lipolysis in adipose tissue contributes by reducing the FA transport to the liver [117]. Additionally, THs stimulate the responses of catecholamine through enhancement of the expression of the uncoupling proteins in the mitochondria of skeletal muscle and obese cells by regulating the number of adrenergic receptors [16]. While TSH directly affects the hepatocyte cell membranes, it can promote hepatic lipogenesis, gluconeogenesis, and diminish hepatic bile acid synthesis [12, 118]. Raised TSH levels were correlated with higher hepatic lipoprotein lipase activity $[119,120]$. These processes are mediated by THs through genomic and non-genomic mechanisms [121]. The first mechanism occurs with the help of the classical nuclear receptors THR- $\alpha$ and THR- $\beta$ [120]. TSH promotes the TG hepatocyte up-take and endorse liver steatosis through binding to TSH receptor, which sets the hepatic sterol regulatory element-binding transcription factor 1 SREBP-1c activity via the cyclic AMP (cAMP)/protein kinase A(PKA)/peroxisome proliferator-activated receptor- $\alpha$ (PPAR $\alpha)$ (cAMP/PKA/PPAR $\alpha$ ) pathway, paralleling with decreased AMPK function and subsequently raised lipogenesis. TSH can restrain cholesterol biosynthesis by stimulating AMPK-mediated phosphorylation of 3-hydroxy-3-methyl-glutaryl coenzyme A reductase (HMGCR) [122,123].

In addition, there is proof that highlights the indirect regulation of the liver lipid metabolism by the thyroid gland through the central nervous system [124]. TH indirectly drives the transcriptional regulation of liver lipogenesis as a result of its effect on carbohydrate-responsive element-binding protein (ChREBP) and liver $X$ receptors. They can lower the VLDL, LDL, high-density lipoproteins (HDL), and apolipoprotein B100 levels [109]. TH can lower LDL by reducing the proprotein convertase subtilisin/kexin type 9 (PCSK9) levels. PCSK9 is controlled by SREBP-2, and data show that hypothroidism is associated with increased levels of PCSK9 [125]. Among other functions, TH instigates the expression of hepatic $\beta$-hydroxy $\beta$-methylglutaryl-CoA (HMG-CoA) reductase, which through different pathways, maintain constant sterol levels, and of cholesterol 7 alpha-hydroxylase (Cyp7A1) [62,118]. Lower CYP7A1 activity is correlated with higher LDL levels [72]. Experimental studies showed that a THR- $\beta$ and T3 agonist can reduce Cyp7A1 levels and that Cyp7A1-TRs may represent a new therapeutic target [126]. Interestingly, the administration of synthetic THR- $\beta$ agonist (KB2115) reduced LDL serum levels [127]. Furthermore, the THR- $\beta$ agonist (e.g., eprotirome, assobetirome) can lower circulating LDL-cholesterol levels without cardiac secondary effects [128]. A study on rodents showed that mice with a THR- $\alpha$ (Thr $\alpha$ PV/PV) mutation had lower hepatic lipid accumulation and decreased lipogenesis, while a negative mutation in THR- $\beta$ (Thr $\beta$ PV/PV) led to decreased fatty acid b-oxidation and raised PPAR $\delta$ signaling, with subsequently increased lipid up-take and liver steatosis [129]. Additionally, THR- $\alpha$ knockout mice seem to be sheltered against diet-induced hepatic steatosis and peripheral IR [130].

THs perturb the regulation of HDL via enhancement of plasma protein factors like cholesteryl ester transfer protein (CETP), lecithin-cholesterol acyltransferase (LCAT), and hepatic lipase and decrease the synthesis of liver phospholipid (phosphatidylserine and cardiolipin) and sphingolipid species [131]. Dysregulations in this protein metabolism act in synergy with the severity of hypothyroidism [132]. THs increase cholesterol efflux from peripheral tissues through the enhancement of genes such as Apolipoprotein A1 (Apo A1) and scavenger receptor class B member 1 (SRB1) [133]. Another complex mechanism by which THs can modulate lipid metabolism are represented by transcriptional, non-transcriptional, and microRNA mechanisms [134]. For example, via miR181d, THs decrease and import a transcription factor that can modulate the activity of sterol O-acyltransferase 2 (SOAT2), 
which has a crucial role in the conversion of cholesterol to specific esters [135]. T3 may have protective effects against lipotoxic derivatives and its action is regulated via mRna and the activity of liver lipases. Additionally, T3 via hepatic lipophagy transports lipids to lysosomes and enhances FA oxidation, which promotes long term hepatic cell autophagy and damage $[136,137]$. Previous treatment with a high dose of the $\mathrm{T} 3$ hormone led to a decrease in cholesterol levels and promoted weight loss, however, its use was limited because of its serious cardiac side effects [138].

These processes emphasize the hepatic lipidic balance and wealth that is induced and sustained by THs. It is clear that lipidomic signatures have a decisive part in NASH evolution/resolution [139,140], that lipid and cholesterol metabolism alteration is beyond complex, and represent the hallmarks of NAFLD; however, supplementary and sustainable evidence to describe these changes in hypothyroidism and how exactly they connect with TH levels are desired.

\subsection{Glucose and Insulin Metabolism}

Hyperinsulinemia as well as hypothyroidism were reported to contribute to NAFLD development independently of each other [140]. In reduced TH plasma levels, the $\beta$-pancreatic cell sensitivity for glucose is damaged, which leads to reduced insulin secretion. Hence, the lipolysis is impaired postprandial and the transport of FFAs from the adipose tissue to the liver and vice versa increases [141]. Hepatic lipid surplus enhances IR, which leads to the deficient suppression of postprandial glucose production. Furthermore, the esterification of FAs and uptake of TG in the liver are supplied by the hepatic IR $[19,142]$. Glucose homeostasis is impaired by reduced insulin secretion and TG accumulation, which alters the insulin-mediated clamp decreased endogenous glucose production. The raised plasma glucose controls the hepatic DNL [115]. Studies showed that smoking and IR may impact the actions of subclinical hypothyroidism on the lipid profile [143], and that defective insulin mediated lipolysis is suppressed in mild hypothyroidism, but not in severe hypothyroidism [115]. It was reported that insulin resistance is associated with hypothyroidism and that IR sensitivity improves in levothyroxine treated patients [144]. Accentuated hyperglycemia found in hypothyroidism could explain the connection to IR, diabetes onset, and NAFLD development [145].

\subsection{Oxidative Stress and Inflammation}

Oxidative stress and inflammation are one of the items that unlock and sustain many cardiovascular, endocrinological, and liver diseases, hence, early evaluation of markers that indicate their presence should be evaluated. The inflammatory pattern in NAFLD/NASH is usually represented by high TNF- $\alpha$, interleukin-6 (IL6), and chemokine levels [146]. Along with an accumulation of hepatic FFAs and inflammation, malfunction of the mitochondria appears. The altered mitochondria, also called the "powerhouse" of the cell [147], leads to excessive oxidation and overflow of reactive oxygen species (ROS). These ROS products impair the activity of deiodinases [148], enhance lipid peroxidation, activation of the KCs, and of specific pro-inflammatory cytokines. Among them, the TNF- $\alpha$ and transforming growth factor $\beta$ (TGF- $\beta$ ) activate hepatic satellite cells and endorse fibrosis $[149,150]$. THs modulate the hepatocyte mitochondrial function by the uncoupling of oxidative phosphorylation [151], and generate ROS through $\mathrm{Ca}^{2+}$-calcium/calmodulin-dependent protein kinase kinase 2 (CAMKK2)-5'-AMP-activated protein kinase (AMPK) circuit. The hepatic autophagic removal of mitochondria and their biogenesis are both modulated by THs. More than that, by activating $\mathrm{Ca}^{2+}$-AMPK and the cAMP-protein kinase A (PKA) pathways, THs can mediate lipid metabolism [152].

In hypothyroid rodents, researchers have found an inflammation and decreased level of ceramides, which account for decreased cell differentiation and apoptosis [153]. Hashimoto's thyroiditis patients with hypothyroidism have increased serum markers of oxidative stress (e.g., malondialdehyde) [154]. Metabolic products of inadequate fatty acid oxidation set off and worsen liver inflammation, fibrosis, and necrosis $[155,156]$. Recently the 3,5-diiodo-L-thyronine (3,5-T2) molecule has attracted more attention because of its metabolic effects, which are similar to T3, but mainly because of its beneficial actions on mitochondrial function and oxidative stress, which suggest its future introduction as a 
potential clinical drug [157]. More data are needed regarding inflammation and oxidative stress in HIN, which may bring interesting possibilities of new therapeutic targets or biomarkers.

\subsection{Adipokines and Hormones}

One of the mechanisms possibly involved in the hypothyroidism-NAFLD pathogenesis could be represented by adipokine metabolism. Low circulating levels of thyroid hormones influence certain adipocytokines levels such as adiponectin or leptin. Adiponectin can enhance fatty acid oxidation and inhibit DNL through activation of AMP-activated protein kinase [158,159]. Hypothyroid subjects have altered adiponectin levels that can contribute to IR development. The modified adipocytokines registered have hepatotoxic properties, can promote oxygen radical release, and furnish liver inflammation and fibrosis $[160,161]$. Leptin is one hormone that is in charge of appetite modulation, can promote hepatic collagen synthesis hepatic IR, and is involved in hepatic fibrogenesis [162]. High levels of this hormone were found in patients with thyroid disfunction and seems to be correlated with TSH levels and with BMI [163]. Another adipokine studied in NAFLD and hypothyroidism is visfatin. In NAFLD, and especially in NASH subjects, low levels of visfatin have been described, however, an exact explanation behind this association is still unclear [164]. Recently, it was proposed that visfatin could be a promising serum biomarker for monitoring liver disease in younger obese population [165].

In addition to the hormonal branches that are explored in HIN pathogenesis, we mention fibroblast growth factor-21 (FGF-21). FGF-21 is a pleiotropic hormone, and specifically a member of the FGF endocrine subfamily, which expresses hormone-like activities and is considered a major regulator of energy homeostasis [166]. Previously, it was described that NAFLD patients have higher FGF-21 levels compared to heathy subjects and that this can fasten NAFLD progression [167]. More than that study shows that hypothyroid subjects have increased levels of FGF-21 independently of lipid profile [168]. Experimental studies have shown that administration of FGF-21 led to improved glucose clearance, insulin sensitivity, and scaled down TG levels [169]. Few studies investigated how hormonal changes influence HIN. Menopause can induce changes in hormonal status and lipid metabolism. Reduced estrogen production leads to increased plasma cholesterol levels, these changes being similar to those encountered in overt hypothyroidism. Recently, the SardiNIA study found that a postmenopausal status influences the relationship between lipid profile and TSH levels [170]. The particular role of adipokines and other hormones such as estrogens in HIN need further exploration.

There is a fine balance between certain key elements found in metabolic syndrome that are also common seen in NAFLD and/or hypothyroidism. This sophisticated relationship, which incorporates alteration in the lipid, TG, cholesterol metabolism, IR, inflammation and oxidative stress, and the dysfunction of the hepatic hormone, is by some degree shaped by THs (Figure 1). We hope that with a better understanding of HIN pathophysiology, advanced technology can help us find new therapeutic approaches. 


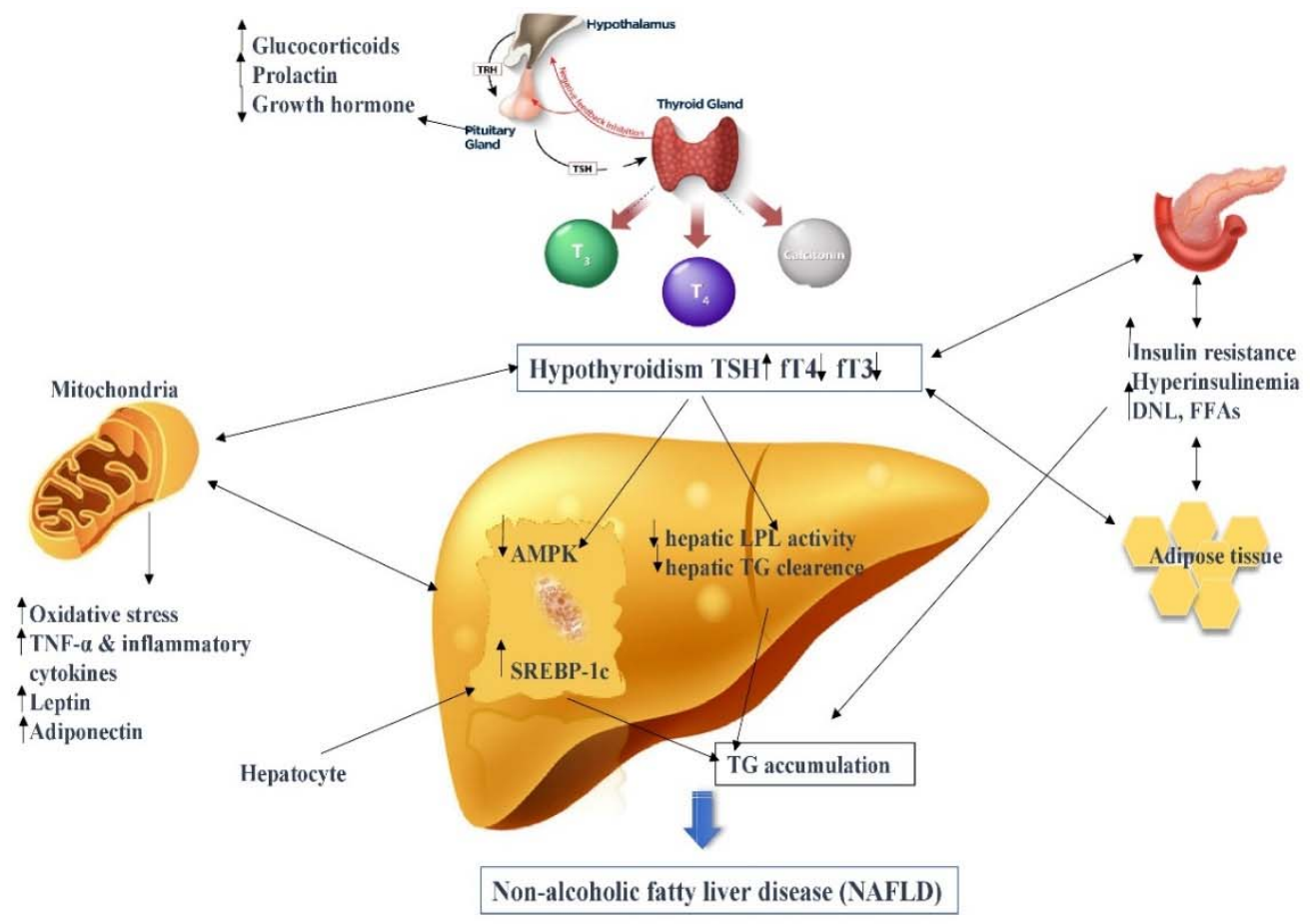

Figure 1. The complex relationship of hypothyroidism-induced NAFLD (HIN). Thyroid stimulating hormone (TSH); free thyroxine (fT4); free triiodothyronine (fT3); de novo lipogenesis (DNL); free fatty acids (FFAs); lipoprotein lipase (LPL); triglycerides (TG); AMP-activated protein kinase (AMPK); sterol regulatory element-binding protein (SREBP-1c); tumor necrosis factor alpha (TNF- $\alpha$ ).

\section{Hypothyroidism-Induced NAFLD Treatment}

Considering the burden of NAFLD and that no current licensed therapy exists, THs and their metabolites, along with the THR- $\beta$ agonist and other liver specific analogs have been tested in the last few years as a potential NAFLD therapy $[7,59,60,171]$.

\subsection{Thyroid Hormones}

The synthetic form of the T4 hormone is levothyroxine sodium, which contains crystalline L-3, $3^{\prime}, 5,5^{\prime}$-tetraiodothyronine sodium salt, having the exact chemical structure of that produced in the human body by the thyroid gland. T3 is the thyroid hormone that produces most of the physiological actions. It is derived mostly from T4 (approximately 80\%) by deiodination in different tissues. THs bind to the DNA receptor proteins after they diffuse into the nucleus and activate gene transcription along with messenger RNA synthesis and production of cytoplasmic proteins. Levothyroxine is absorbed mostly in the gastrointestinal tract (in the jejunum and upper ileum). The level of absorption varies from $40 \%$ to $80 \%$, is increased by fasting, and decreased in malabsorption syndromes. Circulating THs bind to plasmatic proteins like albumin (TBA), thyroxine-binding prealbumin (TBPA), and thyroxine-binding globulin (TBG), but are metabolically active only unbound. The main degradation site for the THs is the liver, but T4 deiodination to T3 and reverse T3 (rT3) also occurs in the kidneys and other tissues. Diiodothyronine is the result of T3 and rT3 deiodination. THs are mostly eliminated through urinary excretion and we have to be aware that it decreases with age [172]. Levothyroxine is the principal treatment for hypothyroidism. It is also associated with a decrease in serum lipids and body mass index (BMI) [77].

In a study published in the International Journal of Endocrinology in 2017, the effect of levothyroxine $\left(\mathrm{LT}_{4}\right)$ treatment on NAFLD resolution was confirmed in patients with subclinical hypothyroidism (SCH). There were two main subgroups: 33 patients with significant SCH (TSH of at least $10 \mathrm{mIU} / \mathrm{L}$ ) and 330 with mild SCH (TSH between 4.2 and $10 \mathrm{mIU} / \mathrm{L}$ ). The second group was further divided into 
one group that received $\mathrm{LT}_{4}$ treatment (181 patients with mild SCH: mild SCH-LT 4 ) and another one that did not (149 patients representing the control group: mild SCH-control group) [173,174]. All those with significant $\mathrm{SCH}$ received $\mathrm{LT}_{4}$ treatment (median $\mathrm{LT}_{4}$ dosage in this group was $75 \mu \mathrm{g}$ per day). Those in the mild $\mathrm{SCH}-\mathrm{LT}_{4}$ group received a median $\mathrm{LT}_{4}$ dosage of $50 \mu \mathrm{g}$ per day [175]. After a 15-month follow-up, the prevalence of NAFLD was reduced in the significant $\mathrm{SCH}$ group from $48.5 \%$ to $24.2 \%(p=0.041)$. There was a moderate reduction in the prevalence of NAFLD in mild SCH patients that received $\mathrm{LT}_{4}$ treatment, but it was not statistically significant (from $44.2 \%$ to $35.9 \%$ with a $p$ value of 0.108). In the mild SCH-control group, there was also a reduction in the NAFLD prevalence from $39.6 \%$ to $34.9 \%(p=0.402)$. These results show that $\mathrm{LT}_{4}$ supplementation can be effective in NAFLD reduction if it is used in patients with significant $\mathrm{SCH}$. There was also a decrease in serum AST value of 5.61 $\mathrm{IU} / \mathrm{L}(p<0.001)$ in significant SCH patients after $\mathrm{LT}_{4}$ treatment, but not a statistically significant one in serum alanine aminotransferase (ALT). $\mathrm{LT}_{4}$ supplementation in the mild $\mathrm{SCH}$ group was associated with a reduction in both AST and ALT, with the last one being marginally significant (from 19.09 $\mathrm{IU} / \mathrm{L}$ to $17.95 \mathrm{IU} / \mathrm{L}, p=0.087$ ). In the mild SCH-control group, serum ALT was stable, but there was a reduction of serum AST. There was a remarkably greater reduction of serum AST in mild SCH-LT 4 patients compared to the mild SCH-control group $(p=0.046)$. Dyslipidemia is also considered to be a risk factor for NAFLD. A subgroup analysis was performed on mild SCH patients that also had dyslipidemia (207 out of 330). The results showed that those that underwent $\mathrm{LT}_{4}$ treatment had higher reductions in NAFLD prevalence and serum liver enzyme values compared to those in the control group. This confirms the strong connection between thyroid function and NAFLD [173,174].

In a 2018 phase IIb trial that took place in six hospitals in Singapore, a significant reduction of hepatic fat was confirmed by magnetic resonance spectroscopy after 16 weeks of low-dose levothyroxine administration. The study included 20 euthyroid patients who had already been diagnosed with type 2 diabetes and NAFLD [175].

T3 (3,5,3'-triiodo-L-thyronine) is known to regulate numerous physiological processes, with one of the most targeted organs being the liver [176]. Exogenous administration of T3 after a choline-methionine deficient (CMD) diet that induces hepatic triglycerides accumulation decreased liver steatosis [177]. T3 promoted fatty acid peroxisomal and mitochondrial $\beta$-oxidation. Furthermore, it decreased hepatic fatty acid-binding protein (L-FABP) expression [178]. In addition, lipid peroxidation and expression of cyclooxygenase-2 (COX-2) were reduced. There was a noted decrease in phosphor-stress-activated protein kinase/c-Jun NH2-terminal kinase (phosphor-SAPK/JNK) and phosphor-signal transducer and activator of transcription 3 (phosphor-STAT3) levels $[179,180]$. Cable and co-workers demonstrated on rats that $\mathrm{T} 3$ reduces the hepatic $\mathrm{mRNA}$ levels of apolipoprotein C3 (ApoC3) and sterol regulatory element binding protein-1c (SREBP-1c). Moreover, it increases peroxisome proliferator-activated receptor $\gamma$ coactivator- $1 \alpha$ (PGC- $1 \alpha$ ) and apolipoprotein A1 (ApoA1) levels [181]. According to a recent study conducted on high fat diet (HFD) rats, T3 increases carnitine palmitoyltransferase-1 (CPT-1) levels with a significant decrease in liver fat content [131]. Other studies have suggested that $\mathrm{TH}$ s induce hepatic autophagy in order to provide the mitochondria with fatty acids [182]. In a 2014 study performed on hypothyroid mice, T3 restored the level of saturated fatty acid. In addition, the expression of acetyl-CoA carboxylase 1 and enzymes used in de novo lipogenesis was increased after T3 treatment. Stearoyl-CoA desaturase-1 activity was suppressed by TH administration, suggesting that they might decrease triglyceride accumulation in the liver [106]. Furthermore, there is growing interest in the possible T3 central effects on the liver. Alvarez-Crespo observed in a 2016 study how T3 chronic central infusion influenced adipose tissue activity and thermogenesis [183]. Unfortunately, increased T3 levels are known to have cardiac, muscle, and bone harmful effects [184].

\subsection{Thyroid Hormone Metabolites}

In the last few decades, T2 (3,5-diiodo-L-thyronine) has emerged as a bioactive TH-related compound. Most in vitro experiments suggest that T2 results after T3 deiodination, having a significantly lower affinity for THRs compared to T3. There are three main selenoenzymes that trigger 
deiodination, out of which type 2 deiodinase (D2) seems to be the one involved in T2 formation [185,186]. Both in vitro and in vivo models observed that $\mathrm{T} 2$ has significant effects on the reduction of hepatic lipid accumulation resulted after exposure to HFD. It also had an impact on the reduction of acyl-CoA oxidase (AOX) activity and peroxisomal $\beta$-oxidation [187]. Further studies suggested that T2 acts directly by activating hepatic nuclear sirtuin 1 (STIR1) [188]. Recently, in a 2017 study performed on HFD fed rats, the effects of T2 on hepatic metabolism were observed in parallel to those of T3. They both decreased hepatic triglyceride levels and induced liver autophagy along with intra-hepatic acylcarnitine accumulation. In addition, they prevented sphingolipid-ceramide generation, but only $\mathrm{T} 2$ rescued the impairment caused by HFD in protein kinase B (AKT) and mitogen-activated protein kinase/extracellular signal-regulated kinase (MAPK/ERK) [131]. T2 achieves the inhibition of liver fat accumulation by decreasing lipogenesis and increasing fatty acid oxidation [188]. Used at a higher dose, T2 had potential cardiac side effects [178]. A functional analog of T2 (TRC150094, TRC) also had an impact in reducing hepatic triglyceride content in HFD rats by increasing oxidation and mitochondrial fatty acid import, without any undesirable effects [189]. Type 3 deiodinase (D3) generates rT3 from T4 and 3,3'-diiodo-L-thyronine (3,3'-T2), another form of T2, from T3. A higher affinity for THRs was observed for 3,3'-T2 in HFD-fed mice, but had a significant negative impact on metabolic parameters $[186,190]$.

Another TH metabolite is 3-iodothyronamine (T1AM), which does not bind to THR, but mediates its effects through the trace amine-associated receptor (TAAR1) [191]. Recent studies demonstrated that T1AM influences body weight and different metabolic pathways that are usually associated with NAFLD [192]. In addition, T1AM reaches higher concentrations at the hepatic level, which is why it is considered that its metabolic effects are partly mediated by hepatocytes [193]. HepG2 cells had a significant T1AM uptake, with an increase in glucose production. There was also an increase in the production of ketone bodies at the hepatic level, which might be correlated with pyruvate and amino acid catabolism [194]. Furthermore, in normal hepatocytes, a direct inducing fatty acid catabolism was observed. Chronic T1AM administration was correlated with a lipolytic pattern, confirmed by in vivo studies that associated significant weight loss [195]. Assadi-Porter and colleagues demonstrated in a 2018 study that the increased fat oxidation observed at a hepatic level comes not only from elevated ketone bodies (3-hydroxybutyrate and acetone), but also from carnitine and succinate. Furthermore, they determined that T1AM effects on lipid hepatic metabolism were dose-dependent [196].

\subsection{Alternative Treatment}

In a recent study published in 2019, thymoquinone (TQ) is used for restoring the liver structure to its initial state after induced hypothyroid NAFLD. TQ is the main constituent of Nigella salvia (NG), a medicinal plant representing the Ranunculaceae family [197]. NG is mostly used for its antioxidant and anti-inflammatory properties, but it also has an immunomodulatory effect [198]. Experimental hypothyroidism was confirmed by the reduction of $\mathrm{T} 3$ and $\mathrm{T} 4$, associated with a significantly increased TSH in the serum of rats that were given 6-propyl-2-thiouracil (PTU) for two weeks. After that, they were divided into a group that continued PTU administration and another one that had concomitant administration of PTU and TQ for the next four weeks. There was also a control group and one that received TQ for six weeks. The livers of the rats were processed for obtaining paraffin blocks and Hematoxylin and Eosin and Streptavidin-Biotin-Peroxidase staining were used. The structure and general architecture of the livers were slightly affected and those of the group treated with PTU showed fatty degeneration (steatosis) in the form of microvesicles and macrovesicles within the hepatocytes. Additionally, alongside classical fatty lesions, intralobular inflammatory reaction was observed. In the group treated with PTU $+\mathrm{TQ}$, resolution of the steatotic lesions and that of steatohepatitis was observed. There was also a decrease in NAFLD activity scores and lobular inflammation. Advanced fibrosis was detected through alpha-smooth muscle actin ( $\alpha$-SMA) staining [199]. A significant increase in the $\alpha$-SMA reaction in the livers of the PTU treated group was observed mainly in the portal region associated with focal inflammatory response areas. 
The $\alpha$-SMA index was restored to that of the control group after TQ administration. $\alpha$-SMA staining was also used in the detection of activated hepatic stellate cells (HSCs) [200], which is a key element in hypothyroidism induced NAFLD. Anti-CD68 antibodies were used to evaluate the number of hepatic macrophages (Kupffer cells). It is known that Kupffer cells are activated by liver injury, which leads to HSC activation and fibrogenesis [201]. There was an important increase in the portal and intralobular $\mathrm{CD}^{+} 8^{+}$cells in the PTU treated group compared to the PTU + TQ and control groups. The main defense mechanism of the liver against the harmful effect of reactive oxygen species (ROS) is exerted by the catalase (CAT) enzyme. It was demonstrated by Subudhi and Chainy that CAT regulation is one of the functions of thyroid hormones [202]. Upregulation of CAT gene expression at a hepatic level in PTU rats that were treated with TQ demonstrated the antioxidant effect of TQ that can annihilate the oxidative stress effect of hypothyroidism on the liver [203].

\section{THR- $\beta$ Selective Thyromimetics and NAFLD}

THs have affinities for both THR- $\alpha$ and THR- $\beta$, this is why their use is limited due to potential adverse reactions that result mostly from THR- $\alpha$ activation [204]. Molecules targeting specific thyroid hormone receptors have been tested. The main thyroid hormone receptor expressed in hepatocytes that regulate metabolic pathways involved in the pathogenesis of NAFLD is THR- $\beta$ [182]. Triiodothyronine and thyroxine have beneficial metabolic effects on cholesterol and triglycerides by targeting the hepatic THR- $\beta$. The first molecules of THR- $\beta$-selective agonists were sobetirome (GC-1) and eprotirome (KB-2115) [103]. In a 2008 study performed on rats, the effects of T3 and GC-1 (a synthetic TH analog that binds to THR- $\beta 1$ with the same affinity as T3) on CMD diet-induced NAFLD/NASH were analyzed. Both T3 and GC-1 prevented hepatic fat accumulation by increasing fatty acid $\beta$-oxidation. In addition, there was hepatosteatosis regression due to a decrease in lipid peroxidation and expression of COX-2, associated with phospho-STAT3 and phospho-SAPK/JNK activation [179]. Further studies showed that GC-1 did not have the requisite safety profile causing insulin resistance and hyperglycemia, so it has not been used as a treatment in NAFLD $[103,204]$. KB-2115 was tested in a 2013 study on fat-fed rats and had statistically significant results in reducing hepatic steatosis, but also decreased GLUT4 skeletal muscle content [204]. In a 2015 parallel study for sobetirome and eprotirome, they both had a significant effect in lowering cholesterol serum levels, but eprotirome long-term use resulted in cartilage disruption in dogs [205]. Another orally active THR- $\beta$ agonist used to reduce hepatic steatosis in a 2009 study on rats and mice is MB07811. It was demonstrated that it increases $\beta$-oxidation and mitochondrial respiration rates, reducing hepatic triglycerides [156]. Most THR- $\beta$-selective agonists had important adverse effects and the studies did not go any further, even though they had a major role in reducing the circulating lipids [103].

The latest selective thyroid hormone $\beta$-receptor agonist is resmetirom (MGL-3196). It is orally active and liver-directed with a higher selection rate than triiodothyronine for THR- $\beta$ compared to thyroid receptor $\alpha$ (THR- $\alpha$ ) [206]. MGL-3196 also has a very high protein bound (above 99\%) with very good hepatic tissue penetration, showing specificity for the liver. Testing of resmetirom on animal models showed that it has an important role in reducing hepatic triglycerides, lipid peroxidation, ALT, steatosis, inflammation, and fibrosis $[157,205]$. In a 36-week randomized study that was double-blinded and placebo-controlled and took place in 25 USA centers, only adults with biopsy confirmed NASH (stages 1-3 of fibrosis) were enrolled and the eligible ones were those who had a hepatic fat fraction above $10 \%$ at MRI-proton density fat fraction (MRI-PDFF). Patients that had associated hypothyroidism with thyroxine treatment doses $>75 \mu \mathrm{g}$ daily were not included in the study. A history of alcohol consumption, drug induced NAFLD, uncontrolled type 2 diabetes (the value of glycated hemoglobin $\geq 9.5 \%$ ), or use of glucagon-like peptide analog (unless they were using it for more than six months before screening on a stable dose) were also exclusion criteria. In addition, patients with severe hepatic dysfunction (hepatic decompensation, cirrhosis, or other chronic liver diseases) and with elevated (five times more the upper limit of normal range) serum ALT or aspartate AST were not included. This phase 2 study used an atypical dosing regimen by administrating $80 \mathrm{mg}$ per day with a possible 
dose adjustment $( \pm 20 \mathrm{mg} /$ day) after four weeks. The study concluded that resmetirom (administrated daily in oral doses) had a significant impact on the reduction of the hepatic fat fraction (measured by MRI-PDFF). The relative liver fat reduction after 12 weeks of treatment was $26.7 \%$ compared to the baseline (placebo adjusted), associated with a relative reduction in ALT of 5.8\% from the baseline (placebo adjusted). There was a sustained reduction in hepatic fat after 36 weeks of treatment (29\% relative reduction from baseline, placebo adjusted) [207]. In addition, resmetirom therapy had a notable impact on the reduction of atherogenic lipids and lipoproteins such as triglycerides, LDL cholesterol, apolipoproteins B and CIII, and lipoprotein(a) [207]. There were improvements in the levels of liver injury markers and fibrosis, with reduced features of NASH on liver biopsy in $27 \%$ of those who underwent resmetirom therapy compared with $6 \%$ of patients that received placebo $[208,209]$. One of the mechanisms through which resmetirom reduces liver fat is thought to be the increase of mitochondrial $\beta$ oxidation [157]. It is also assumed that resmetirom reduces VLDL production and secretion, lowering LDL cholesterol, triglycerides, and apolipoprotein B plasma concentrations. The mechanism through which MGL-3196 reduces serum concentration of lipoprotein(a) is still unknown [210]. Another THR- $\beta$ selective agonist, VK2809 (MB 07811), was used in a 12-week phase 2 study as a treatment for patients with NAFLD. The subjects received $10 \mathrm{mg}$ of VK2809 per day and at the end of the study, there was a 50.8\% liver fat reduction from the baseline (placebo adjusted) [211]. In a 2016 study, a hybrid molecule composed of glucagon and T3 was tested, targeting synchronized signaling in order to minimize the adverse effects of each hormone. Glucagon/T3 conjugates had a beneficial impact in reducing hepatic fat in metabolically compromised mice, without cardiovascular or bone toxicity. These findings open a new era for chronic treatment in the vast number of pathologies that constitute what we call metabolic syndrome including NAFLD [212]. Based on the available evidence (Table 1), we conclude that further research should be focused on this issue, especially given the prevalence of NAFLD associated with hypothyroidism. 
Table 1. The impact of TH therapy on liver function in NAFLD. Nonalcoholic fatty liver disease (NAFLD); 6-propyl-2-thiouracil (PTU); nonalcoholic steatohepatitis (NASH); thyroid hormone receptor $\beta$ (THR- $\beta$ ); low-density lipoproteins (LDL); choline-methionine deficient (CMD); cyclooxygenase-2 (COX-2); phosphor-signal transducer and activator of transcription 3 (phospho-STAT3); phosphor-stress-activated protein kinase/c-Jun NH2-terminal kinase (phospho-SAPK/JNK); high fat diet (HFD); protein kinase B (AKT); mitogen-activated protein kinase/extracellular signal-regulated kinase (MAPK/ERK); carnitine palmitoyltransferase-1 (CPT-1); messenger RNA (mRNA); apolipoprotein C3 (ApoC3); apolipoprotein A1 (ApoA1); sterol regulatory element-binding transcription factor 1 (SREBP-1c); peroxisome proliferator-activated receptor $\gamma$ coactivator- $1 \alpha$ (PGC- $1 \alpha)$; liver fatty acid binding protein (L-FABP); levothyroxine ( $\left.\mathrm{LT}_{4}\right)$; subclinical hypothyroidism (SCH).

\begin{tabular}{|c|c|c|c|c|c|}
\hline & Country & Year & Main Findings & NAFLD Impact & First Author (Reference) \\
\hline \multicolumn{6}{|c|}{ Thyroid hormones } \\
\hline \multirow[t]{2}{*}{ Levothyroxine (T4) } & China & 2017 & $\begin{array}{l}\text { - LT4 replacement therapy had beneficial impact in } \\
\text { patients with significant SCH or mild SCH } \\
\text { with dyslipidemia }\end{array}$ & - NAFLD reduction in patients with significant $\mathrm{SCH}$ & Liu, L. [174] \\
\hline & Singapore & 2018 & $\begin{array}{l}\text { low-dose LT4 therapy decreased intrahepatic lipid } \\
\text { content in } 20 \text { euthyroid male patients diagnosed with } \\
\text { type } 2 \text { diabetes }\end{array}$ & $\begin{array}{l}\text { - significant reduction of hepatic fat in a small group } \\
\text { of patients }\end{array}$ & Bruinstroop, E. [175] \\
\hline \multirow[t]{5}{*}{ Triiodothyronine (T3) } & Italy & 2008 & $\begin{array}{l}\text { - } \quad \text { promoted fatty acid peroxisomal and mitochondrial } \\
\text { - } \quad \text {-oxidation } \\
\text { - } \quad \text { recreased L-FABP expression lipid peroxidation and COX-2 expression } \\
\text { - decreased phosphor-SAPK/JNK and } \\
\text { phosphor-STAT3 levels }\end{array}$ & $\begin{array}{l}\text { - decreased CMD diet-induced hepatosteatosis } \\
\text { in rats } \\
\text { - prevented hepatic fat accumulation by increasing } \\
\text { fatty acid } \beta \text {-oxidation }\end{array}$ & Perra, A. [179] \\
\hline & USA & 2009 & 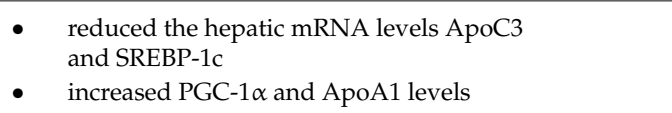 & $\begin{array}{l}\text { - induced adipocyte lipolysis } \\
\text { - }\end{array}$ & Cable, E.E. [181] \\
\hline & China & 2014 & $\begin{array}{l}\text { - restored the level of saturated fatty acid } \\
\text { - increased expression of acetyl-CoA carboxylase } 1 \text { and } \\
\text { other enzymes used in de novo lipogenesis }\end{array}$ & $\begin{array}{l}\text { stearoyl-CoA desaturase-1 activity was suppressed } \\
\text { by TH administration, suggesting that they might } \\
\text { decrease triglyceride accumulation in the liver }\end{array}$ & Yao, X. [106] \\
\hline & Spain & 2016 & $\begin{array}{l}\text { - chronic central infusion influences adipose tissue } \\
\text { activity and thermogenesis }\end{array}$ & - & Alvarez-Crespo, M. [183] \\
\hline & Italy & 2017 & - increased CPT-1 levels & $\begin{array}{l}\text { - significant decrease in liver fat content in } \\
\text { HFD-fed rats }\end{array}$ & Iannucci, L.F. [131] \\
\hline
\end{tabular}


Table 1. Cont.

\begin{tabular}{|c|c|c|c|c|c|}
\hline & Country & Year & Main Findings & NAFLD Impact & First Author (Reference) \\
\hline \multicolumn{6}{|c|}{ Thyroid hormones metabolites } \\
\hline \multirow[t]{3}{*}{$\begin{array}{c}\mathrm{T} 2 \\
\text { (3,5-diiodo-L-thyronine) }\end{array}$} & Italy & 2017 & $\begin{array}{l}\text { reduction of acyl-CoA oxidase activity and } \\
\text { peroxisomal } \beta \text {-oxidation }\end{array}$ & $\begin{array}{l}\text { - reduction of hepatic lipid accumulation resulted } \\
\text { after exposure to HFD }\end{array}$ & Grasselli, E. [187] \\
\hline & Italy & 2017 & $\begin{array}{l}\text { - prevented sphingolipid-ceramides generation } \\
\text { rescued the impairment caused by HFD in AKT and } \\
\text { MAPK/ERK }\end{array}$ & $\begin{array}{l}\text { - decreased hepatic triglyceride levels and induced } \\
\text { liver autophagy along with intra-hepatic } \\
\text { acylcarnitine accumulation in HFD fed rats }\end{array}$ & Iannucci, L.F. [131] \\
\hline & Italy & 2017 & $\begin{array}{l}\text { - } \quad \text { decreased lipogenesis } \\
\text { increased fatty acid oxidation }\end{array}$ & - inhibition of liver fat accumulation & Senese, R. [188] \\
\hline \multirow[t]{2}{*}{$\begin{array}{c}\text { T1AM } \\
\text { (3-iodothyronamine) }\end{array}$} & Italy & 2014 & $\begin{array}{l}\text { - T1AM reached higher concentrations at hepatic level } \\
\text { increased the production of ketone bodies at } \\
\text { hepatic level }\end{array}$ & - & Ghelardoni, S. [193] \\
\hline & USA & 2018 & $\begin{array}{l}\text { - increased fat oxidation observed at a hepatic level } \\
\text { comes also from carnitine and succinate }\end{array}$ & $\begin{array}{l}\text { - dose-dependent effects on lipid } \\
\text { hepatic metabolism }\end{array}$ & Assadi-Porter, F.M. [196] \\
\hline \multicolumn{6}{|c|}{ THR- $\beta$ Selective Thyromimetics } \\
\hline Sobetirome (GC-1) & Italy & 2008 & $\begin{array}{l}\text { - decreased lipid peroxidation and expression of COX-2, } \\
\text { associated with phospho-STAT3 and } \\
\text { phospho-SAPK/JNK activation }\end{array}$ & $\begin{array}{l}\text { - decreased CMD diet-induced hepatosteatosis } \\
\text { in rats } \\
\text { prevented hepatic fat accumulation by increasing } \\
\text { fatty acid } \beta \text {-oxidation }\end{array}$ & Perra, A. [179] \\
\hline \multirow[t]{2}{*}{ Eprotirome (KB-2115) } & USA & 2013 & - decreased GLUT4 skeletal muscle content & $\begin{array}{l}\text { - significant reduction of hepatic steatosis in } \\
\text { fat-fed rats }\end{array}$ & Vatner, D.F. [204] \\
\hline & USA & 2015 & $\begin{array}{l}\text { - long term use resulted in cartilage disruption in dogs } \\
\text { - }\end{array}$ & - & Lammel Lindemann, J. [205] \\
\hline MB07811 & USA & 2009 & $\begin{array}{l}\text { increased } \beta \text {-oxidation and mitochondrial respiration } \\
\text { rates, reducing hepatic triglycerides }\end{array}$ & - reduction of hepatic steatosis in rats and mice & Cable, E.E. [181] \\
\hline Resmetirom (MGL-3196) & USA & 2019 & $\begin{array}{l}\text { - reduced atherogenic lipids and lipoproteins, such as } \\
\text { triglycerides, LDL cholesterol, apolipoproteins B and } \\
\text { CIII, and lipoprotein(a) }\end{array}$ & $\begin{array}{l}\text { - significant impact on the reduction of the hepatic } \\
\text { fat fraction }\end{array}$ & Harrison, S.A. [207] \\
\hline VK2809 (MB 07811) & USA & 2018 & $\begin{array}{l}\text { - further development as a low-dose THR- } \beta \text { selective } \\
\text { thyromimetic for NASH patients }\end{array}$ & $\begin{array}{l}\text { - } 50.8 \% \text { liver fat reduction from baseline in } \\
\text { NAFLD patients }\end{array}$ & Loomba, R. [211] \\
\hline
\end{tabular}


Table 1. Cont.

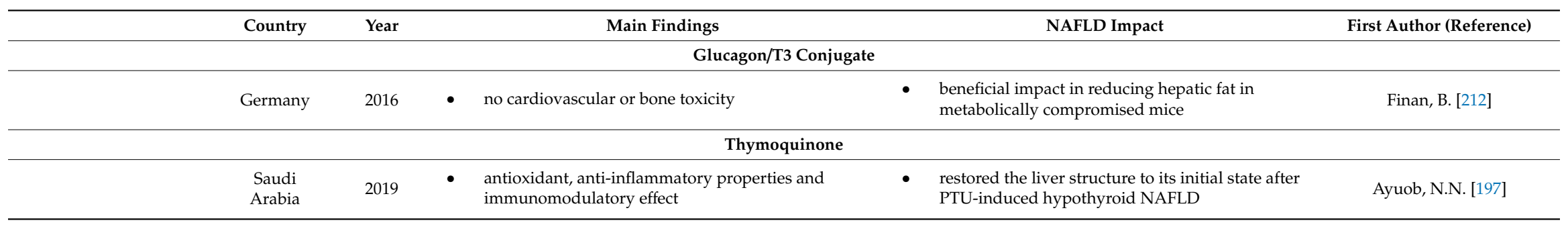




\section{Conclusions}

Robust evidence is needed to delineate the nature behind NAFLD-hypothyroidism pathogenesis, how they influence each other, and if, in the near future, a program of detecting the thyroid function in NAFLD patients would be beneficial. As NAFLD specific treatment is still unavailable and its management relies most on lifestyle changes, we may not be as reluctant to test thyroid parameters in these patients. Of interest is thyroid replacement therapy that could improve disease progression and lead to better outcomes. New larger clinical trials are needed to assess sufficient evidence that support and complement the existing hypothesis, and perhaps find the best therapy options for these two combined diseases.

Author Contributions: Conceptualization, D.M.T., E.M.G. and E.N.; Methodology, M.C., C.F.C., and M.F.; Software, C.F.C.; Validation, L.L.C., C.C.T., and M.F.; Formal analysis, E.M.G. and E.N.; Investigation, D.M.T., E.M.G., M.F., and M.C.; Resources, E.N.; Data curation, C.C.T., L.L.H., and C.F.C.; Writing original draft preparation, E.M.G. and E.N.; Writing review and editing, D.M.T., E.M.G., and M.F.; Visualization, E.N.; Supervision, M.C.; Project administration, D.M.T.; Funding acquisition, L.L.H. and C.C.T. All authors have read and agreed to the published version of the manuscript.

Funding: This research received no external funding.

Conflicts of Interest: The authors declare no conflict of interest.

\section{Abbreviations}

$\begin{array}{ll}\text { NAFLD } & \text { Nonalcoholic fatty liver disease } \\ \text { NAFL } & \text { Nonalcoholic fatty liver } \\ \text { NASH } & \text { Nonalcoholic steatohepatitis } \\ \text { THs } & \text { Thyroid hormones } \\ \text { HCs } & \text { Hepatic cells } \\ \text { HCC } & \text { Hepatocellular carcinoma } \\ \text { HIN } & \text { Hypothyroidism-induced NAFLD } \\ \text { SCH } & \text { Subclinical hypothyroidism } \\ \text { IR } & \text { Insulin resistance } \\ \text { BMI } & \text { Body mass index } \\ \text { TSH } & \text { Thyroid-stimulating hormone } \\ \text { fT4 } & \text { Free Thyroxine } \\ \text { LT } 4 & \text { Levothyroxine } \\ \text { AST } & \text { Aspartate aminotransferase } \\ \text { ALT } & \text { Alanine aminotransferase } \\ \text { TG } & \text { Triglyceride } \\ \text { HOMA-IR } & \text { Homeostatic Model Assessment for Insulin Resistance } \\ \text { TRs } & \text { Thyroid hormone receptors } \\ \text { T3 } & 3,5,3^{\prime} \text {-triiodothyronine } \\ \text { T4 } & 3,5,3^{\prime}, 5^{\prime} \text {-tetraiodothyronine } \\ \text { rT3 } & \text { Reverse T3 } \\ \text { TRH } & \text { Thyrotropin-releasing hormone } \\ \text { RXR } & \text { Retinoid X receptor } \\ \text { TREs } & \text { Thyroid hormone response elements } \\ \text { THR- } \alpha & \text { Thyroid hormone receptor } \alpha 1 \\ \text { THR- } \beta & \text { Thyroid hormone receptor } \beta 1 \\ \text { D1 } & \text { Deiodinases 1 } \\ \text { D2 } & \text { Deiodinases 2 } \\ \text { D3 } & \text { Deiodinases 3 } \\ \text { T2 } & \text { Diiodothyronine } \\ \text { TGF- } \beta & \text { Transforming growth factor-beta } \\ \text { IL6 } & \end{array}$


FFAs

DNL

L-FABPs

SREBP-1C

ChREBP

PCSK9

HMG-CoA

Cyp7A1

T2DM

CKD

MRI

FLI

USG

LS

CSS

CCS

WAT

mRNA

FAS

ACC

VLDL

LDL

HDL

FATPs

FAT

cAMP

PKA

PPAR $\alpha$

PPAR $\delta$

AMPK

HMGCR

CETP

LCAT

ApoA1

ApoC3

SRB1

SOAT2

ROS

CAT

CAMKK2

FGF-21

TBA

TBPA

TBG

L-FABP

CMD

COX-2

AOX

phosphor-SAPK/JNK

phosphor-STAT3

PGC- $1 \alpha$

CPT-1
Free fatty acids

De novo lipogenesis

Liver fatty acid binding proteins

Sterol regulatory element-binding transcription factor 1

Carbohydrate- Responsive Element-Binding Protein

Proprotein convertase subtilisin/kexin type 9

$\beta$-Hydroxy $\beta$-methylglutaryl-CoA

Cholesterol 7 alpha-hydroxylase

Type 2 diabetes mellitus

Chronic kidney disease

Magnetic Resonance Imaging

Fatty liver index

Ultrasonography

Longitudinal study

Cross-sectional study

Case-control study

White adipose tissue

Messenger RNA

Fatty acid synthase

Acetyl-CoA carboxylase

Very-low-density lipoprotein

Low-Density Lipoproteins

High-Density Lipoproteins

Fatty acid transporter proteins

Fatty acid translocase

Cyclic AMP

Protein kinase A

Peroxisome proliferator-activated receptor- $\alpha$

Peroxisome proliferator-activated receptor- $\delta$

AMP-activated protein kinase

3-hydroxy-3-methyl-glutaryl coenzyme A reductase

Cholesteryl ester transfer protein

Lecithin-cholesterol acyltransferase

Apolipoprotein A1

Apolipoprotein C3

Scavenger receptor class B member 1

Sterol O-acyltransferase 2

Reactive oxygen species

Catalase

$\mathrm{Ca}^{2+}$-calcium/calmodulin-dependent protein kinase kinase 2

Fibroblast growth factor-21

Thyroxine-binding albumin

Thyroxine-binding prealbumin

Thyroxine-binding globulin

Hepatic fatty acid-binding protein

Choline-methionine deficient

Cyclooxygenase-2

Acyl-CoA oxidase

Phosphor-stress-activated protein kinase/c-Jun NH2-terminal kinase

Phosphor-signal transducer and activator of transcription 3

Peroxisome proliferator-activated receptor $\gamma$ coactivator- $1 \alpha$

Carnitine palmitoyltransferase-1 


$\begin{array}{ll}\text { T1AM } & \text { 3-iodothyronamine } \\ \text { STIR1 } & \text { Hepatic nuclear sirtuin 1 } \\ \text { AKT } & \text { Protein kinase B } \\ \text { MAPK/ERK } & \text { Mitogen-activated protein kinase/extracellular signal-regulated kinase } \\ \text { TAAR1 } & \text { Trace amine-associated receptor } \\ \text { TQ } & \text { Thymoquinone } \\ \text { NG } & \text { Nigella salvia } \\ \text { PTU } & \text { 6-propyl-2-thiouracil } \\ \alpha-S M A & \text { Alpha-smooth muscle actin } \\ \text { HSCs } & \text { Hepatic stellate cells } \\ \text { GC-1 } & \text { Sobetirome } \\ \text { KB-2115 } & \text { Eprotirome } \\ \text { MGL-3196 } & \text { Resmetirom } \\ \text { MRI-PDFF } & \text { MRI-proton density fat fraction }\end{array}$

\section{References}

1. Younossi, Z.; Tacke, F.; Arrese, M.; Sharma, B.C.; Mostafa, I.; Bugianesi, E.; Wong, V.W.; Yilmaz, Y.; George, J.; Fan, J.; et al. Global Perspectives on Non-alcoholic Fatty Liver Disease and Non-alcoholic Steatohepatitis. Hepatology 2019, 69, 2672-2682. [CrossRef]

2. Younossi, Z.; Anstee, Q.M.; Marietti, M.; Hardy, T.; Henry, L.; Eslam, M.; George, J.; Bugianesi, E. Global burden of NAFLD and NASH: Trends, predictions, risk factors and prevention. Nat. Rev. Gastroenterol. Hepatol. 2018, 15, 11-20. [CrossRef] [PubMed]

3. Buzzetti, E.; Pinzani, M.; Tsochatzis, E.A. The multiple-hit pathogenesis of non-alcoholic fatty liver disease (NAFLD). Metabolism 2016, 65, 1038-1048. [CrossRef] [PubMed]

4. Chalasani, N.; Younossi, Z.; Lavine, J.E.; Charlton, M.; Cusi, K.; Rinella, M.; Harrison, S.A.; Brunt, E.M.; Sanyal, A.J. The diagnosis and management of nonalcoholic fatty liver disease: Practice guidance from the American Association for the Study of Liver Diseases. Hepatology 2018, 67, 328-357. [CrossRef]

5. Italian Association for the Study of the Liver (AISF). AISF position paper on nonalcoholic fatty liver disease (NAFLD): Updates and future directions. Dig. Liver Dis. 2017, 49, 471-483. [CrossRef] [PubMed]

6. Singal, A.K.; Hasanin, M.; Kaif, M.; Wiesner, R.; Kuo, Y.F. Nonalcoholic Steatohepatitis is the Most Rapidly Growing Indication for Simultaneous Liver Kidney Transplantation in the United States. Transplantation 2016, 100, 607-612. [CrossRef] [PubMed]

7. Li, A.A.; Ahmed, A.; Kim, D. Extrahepatic Manifestations of Nonalcoholic Fatty Liver Disease. Gut Liver 2020, 14, 168-178. [CrossRef]

8. Wattacheril, J. Extrahepatic Manifestations of Nonalcoholic Fatty Liver Disease. Gastroenterol. Clin. N. Am. 2020, 49, 141-149. [CrossRef]

9. Rosato, V.; Masarone, M.; Dallio, M.; Federico, A.; Aglitti, A.; Persico, M. NAFLD and Extra-Hepatic Comorbidities: Current Evidence on a Multi-Organ Metabolic Syndrome. Int. J. Environ. Res. Public Health 2019, 16, 3415. [CrossRef]

10. Adams, L.A.; Anstee, Q.M.; Tilg, H.; Targher, G. Non-alcoholic fatty liver disease and its relationship with cardiovascular disease and other extrahepatic diseases. Gut 2017, 66, 1138-1153. [CrossRef]

11. Hazlehurst, J.M.; Tomlinson, J.W. Non-alcoholic fatty liver disease in common endocrine disorders. Eur. J. Endocrinol. 2013, 169, R27-R37. [CrossRef] [PubMed]

12. Wang, T.; Yang, W.; Karakas, S.; Sarkar, S. NASH in Nondiabetic Endocrine Disorders. Metab. Syndr. Relat. Disord. 2018, 16, 315-320. [CrossRef] [PubMed]

13. Lonardo, A.; Nascimbeni, F.; Mantovani, A.; Targher, G. Hypertension, diabetes, atherosclerosis and NASH: Cause or consequence? J. Hepatol. 2018, 68, 335-352. [CrossRef]

14. Ballestri, S.; Mantovani, A.; Nascimbeni, F.; Lugari, S.; Lonardo, A. Extra-hepatic manifestations and complications of nonalcoholic fatty liver disease. Future Med. Chem. 2019, 11, 2171-2192. [CrossRef]

15. Blum, M.R.; Gencer, B.; Adam, L.; Feller, M.; Collet, T.H.; da Costa, B.R. Impact of thyroid hormone therapy on atherosclerosis in the elderly with subclinical hypothyroidism: A randomized trial. J. Clin. Endocrinol. Metab. 2018, 103, 2988-2997. [CrossRef] 
16. Demir, Ş.; Ünübol, M.; Aypak, S.Ü.; İpek, E.; Aktaş, S.; Ekren, G.S.; Yılmaz, M.; Tunca, R.; Güney, E. Histopathologic Evaluation of Nonalcoholic Fatty Liver Disease in Hypothyroidism-Induced Rats. Int. J. Endocrinol. 2016, 2016, 5083746. [CrossRef]

17. Jiang, L.; Du, J.; Wu, W.; Fang, J.; Wang, J.; Ding, J. Sex differences in subclinical hypothyroidism and associations with metabolic risk factors: A health examination-based study in mainland China. BMC Endocr. Disord. 2020, 20, 100. [CrossRef]

18. Zhang, X.; Gong, P.; Sheng, L.; Lin, Y.; Fan, Q.; Zhang, Y.; Bao, Y.; Li, S.; Du, H.; Chen, Z.; et al. Prognostic value of subclinical thyroid dysfunction in ischemic stroke patients treated with intravenous thrombolysis. Aging 2019, 11, 6839-6850. [CrossRef]

19. Iwen, K.A.; Oelkrug, R.; Kalscheuer, H.; Brabant, G. Metabolic Syndrome in Thyroid Disease. Front. Horm. Res. 2018, 49, 48-66. [CrossRef]

20. George, K.M.; Lutsey, P.L.; Selvin, E.; Palta, P.; Windham, B.G.; Folsom, A.R. Association Between Thyroid Dysfunction and Incident Dementia in the Atherosclerosis Risk in Communities Neurocognitive Study. J. Endocrinol. Metab. 2019, 9, 82-89. [CrossRef]

21. Alfadhel, M.; Al Othaim, A.; Al Saif, S.; Al Mutairi, F.; Alsayed, M.; Rahbeeni, Z.; Alzaidan, H.; Alowain, M.; Al-Hassnan, Z.; Saeedi, M.; et al. Expanded Newborn Screening Program in Saudi Arabia: Incidence of screened disorders. J. Paediatr. Child Health 2017, 53, 585-591. [CrossRef] [PubMed]

22. Krashin, E.; Piekiełko-Witkowska, A.; Ellis, M.; Ashur-Fabian, O. Thyroid hormones and cancer: A comprehensive review of preclinical and clinical studies. Front. Endocrinol. 2019, 10, 59. [CrossRef] [PubMed]

23. Liu, L.; Li, P.; Mi, Y.; Liu, Y.; Liu, Y.; Zhang, P. Thyroid-stimulating hormone is associated with nonalcoholic steatohepatitis in patients with chronic hepatitis B. Medicine 2019, 98, e17945. [CrossRef] [PubMed]

24. Lonardo, A.; Ballestri, S.; Mantovani, A.; Nascimbeni, F.; Lugari, S.; Targher, G. Pathogenesis of hypothyroidism-induced NAFLD: Evidence for a distinct disease entity? Dig. Liver Dis. 2019, 51, 462-470. [CrossRef] [PubMed]

25. Okosieme, O.; Gilbert, J.; Abraham, P.; Boelaert, K.; Dayan, C.; Gurnell, M.; Leese, G.; McCabe, C.; Perros, P.; Smith, V.; et al. Management of primary hypothyroidism: Statement by the British ThyroidAssociation Executive Committee. Clin. Endocrinol. 2016, 84, 799-808. [CrossRef]

26. Miyake, T.; Matsuura, B.; Furukawa, S.; Todo, Y.; Yamamoto, S.; Yoshida, O.; Imai, Y.; Watanabe, T.; Yamamoto, Y.; Hirooka, M.; et al. Hyperthyroidism Improves the Pathological Condition of Nonalcoholic Steatohepatitis: A Case of Nonalcoholic Steatohepatitis with Graves' Disease. Intern. Med. 2016, 55, 2019-2023. [CrossRef]

27. Feisa, S.V.; Chopei, I.V. Subclinical hypothyroidism in patients with non-alcoholic fatty liver disease at the background of carbohydrate metabolism disorders. Wiad. Lek. 2018, 71, 261-264.

28. Chiovato, L.; Magri, F.; Carlé, A. Hypothyroidism in Context: Where We've Been and Where We're Going. Adv. Ther. 2019, 36, 47-58. [CrossRef]

29. Biondi, B.; Cappola, A.R.; Cooper, D.S. Subclinical Hypothyroidism: A Review. JAMA 2019, 322, $153-160$. [CrossRef]

30. Marchesini, G.; Roden, M.; Vettor, R. Response to: Comment to "EASL-EASD-EASO Clinical Practice Guidelines for the management of non-alcoholic fatty liver disease". J. Hepatol. 2017, 66, 466-467. [CrossRef]

31. Garg, R.; Sait, H.; Jindal, A.; Juneja, M.; Gupta, S.; Thelma, B.K.; Kapoor, S. Factors Associated with Transient Neonatal Hyperthyrotropinemia. Indian J. Pediatr. 2020, 87, 482-483. [CrossRef] [PubMed]

32. Krause, A.J.; Cines, B.; Pogrebniak, E.; Sherafat-Kazemzadeh, R.; Demidowich, A.P.; Galescu, O.A.; Brady, S.M.; Reynolds, J.C.; Hubbard, V.S.; Yanovski, J.A. Associations between adiposity and indicators of thyroid status in children and adolescents. Pediatr. Obes. 2016, 11, 551-558. [CrossRef] [PubMed]

33. Pan, Y.W.; Tsai, M.C.; Yang, Y.J.; Chen, M.Y.; Chen, S.Y.; Chou, Y.Y. The relationship between nonalcoholic fatty liver disease and pediatric congenital hypothyroidism patients. Kaohsiung J. Med. Sci. 2019, 35, 778-786. [CrossRef]

34. Yu, E.L.; Golshan, S.; Harlow, K.E.; Angeles, J.E.; Durelle, J.; Goyal, N.P.; Newton, K.P.; Sawh, M.C.; Hooker, J.; Sy, E.Z.; et al. Prevalence of Nonalcoholic Fatty Liver Disease in Children with Obesity. J. Pediatr. 2019, 207, 64-70. [CrossRef] [PubMed]

35. Kaltenbach, T.E.; Graeter, T.; Oeztuerk, S.; Holzner, D.; Kratzer, W.; Wabitsch, M.; Denzer, C. Thyroid dysfunction and hepatic steatosis in overweight children and adolescents. Pediatr. Obes. 2017, 12, 67-74. [CrossRef] 
36. Wassner, A.J. Pediatric Hypothyroidism: Diagnosis and Treatment. Paediatr. Drugs 2017, 19, $291-301$. [CrossRef] [PubMed]

37. Liangpunsakul, S.; Chalasani, N. Is hypothyroidism a risk factor for non-alcoholic steatohepatitis? J. Clin. Gastroenterol. 2003, 37, 340-343. [CrossRef]

38. Targher, G.; Montagnana, M.; Salvagno, G.; Moghetti, P.; Zoppini, G.; Muggeo, M.; Lippi, G. Association between serum TSH, free T4 and serum liver enzyme activities in a large cohort of unselected outpatients. Clin. Endocrinol. 2008, 68, 481-484. [CrossRef]

39. Silveira, M.G.; Mendes, F.D.; Diehl, N.N.; Enders, F.T.; Lindor, K.D. Thyroid dysfunction in primary biliary cirrhosis, primary sclerosing cholangitis and non-alcoholic fatty liver disease. Liver Int. 2009, 29, 1094-1100. [CrossRef]

40. Moustafa, A.H.; Ali, E.M.; Mohamed, T.M.; Abdou, H.I. Oxidative stress and thyroid hormones in patients with liver diseases. Eur. J. Intern. Med. 2009, 20, 703-708. [CrossRef]

41. Xu, C.; Xu, L.; Yu, C.; Miao, M.; Li, Y. Association between thyroid function and nonalcoholic fatty liver disease in euthyroid elderly Chinese. Clin. Endocrinol. 2011, 75, 240-246. [CrossRef] [PubMed]

42. Chung, G.E.; Kim, D.; Kim, W.; Yim, J.Y.; Park, M.J.; Kim, Y.J.; Yoon, J.H.; Lee, H.S. Non-alcoholic fatty liver disease across the spectrum of hypothyroidism. J. Hepatol. 2012, 57, 150-156. [CrossRef] [PubMed]

43. Pagadala, M.R.; Zein, C.O.; Dasarathy, S.; Yerian, L.M.; Lopez, R.; McCullough, A.J. Prevalence of hypothyroidism in nonalcoholic fatty liver disease. Dig. Dis. Sci. 2012, 57, 528-534. [CrossRef] [PubMed]

44. Carulli, L.; Ballestri, S.; Lonardo, A.; Lami, F.; Violi, E.; Losi, L.; Bonilauri, L.; Verrone, A.M.; Odoardi, M.R.; Scaglioni, F.; et al. Is nonalcoholic steatohepatitis associated with a high-though-normal thyroid stimulating hormone level and lower cholesterol levels? Intern. Emerg. Med. 2013, 8, 297-305. [CrossRef]

45. Tao, Y.; Gu, H.; Wu, J.; Sui, J. Thyroid function is associated with non-alcoholic fatty liver disease in euthyroid subjects. Endocr. Res. 2015, 40, 74-78. [CrossRef]

46. Liu, G.; Zheng, X.; Guan, L.; Jiang, Z.; Lin, H.; Jiang, Q.; Zhang, N.; Zhang, Y.; Zhang, X.; Yu, C.; et al. Free triiodothyronine levels are positively associated with non-alcoholic fatty liver disease in euthyroid middle-aged subjects. Endocr. Res. 2015, 40, 188-193. [CrossRef]

47. Ding, W.J.; Wang, M.M.; Wang, G.S.; Shen, F.; Qin, J.J.; Fan, J.G. Thyroid function is associated with non-alcoholic fatty liver disease in chronic hepatitis B-infected subjects. J. Gastroenterol. Hepatol. 2015, 30, 1753-1758. [CrossRef]

48. Gökmen, F.Y.; Ahbab, S.; Ataoğlu, H.E.; Türker, B.Ç.; Çetin, F.; Türker, F.; Mamaç, R.Y.; Yenigün, M. FT3/FT4 ratio predicts non-alcoholic fatty liver disease independent of metabolic parameters in patients with euthyroidism and hypothyroidism. Clinics 2016, 71, 221-225. [CrossRef]

49. Kim, D.; Kim, W.; Joo, S.K.; Bae, J.M.; Kim, J.H.; Ahmed, A. Subclinical hypothyroidism and low-normal thyroid function are associated with nonalcoholic steatohepatitis and fibrosis. Clin. Gastroenterol. Hepatol. 2018, 16, 123-131. [CrossRef]

50. Uribe, M.; Roman-Sandoval, J.D.J.; Ramos-Ostos, M.; Alfaro-Lara, R.; Mendez-Sanchez, N.; Chavez-Tapia, N.C. Role of subclinical hypothyroidism in nonalcoholic fatty liver disease. J. Diabetes 2011, 3, 202.

51. Xu, L.; Ma, H.; Miao, M.; Li, Y. Impact of subclinical hypothyroidism on the development of non-alcoholic fatty liver disease: A prospective case-control study. J. Hepatol. 2012, 57, 1153-1154. [CrossRef] [PubMed]

52. Parikh, P.; Phadke, A.; Sawant, P. Prevalence of hypothyroidism in nonalcoholic fatty liver disease in patients attending a tertiary hospital in western India. Indian J. Gastroenterol. 2015, 34, 169-173. [CrossRef] [PubMed]

53. Mohanty, R.; Das, S.N.; Jena, A.K.; Behera, S.; Sahu, N.C.; Mohanty, B.; Suna, S.P.; Thatoi, P.K. Prevalence of non-alcoholic fatty liver disease in hypothyroidism in a tertiary care hospital in eastern India. J. Evol. Med. Dent. Sci. 2017, 6, 5589-5593. [CrossRef]

54. Mazo, D.F.; Lima, V.M.; Stefano, J.T.; Rabelo, F.; Faintuch, J.; Oliveira, C.P. Gluco-lipidic indices in treated hypothyroidism associated with nonalcoholic fatty liver disease. Arq. Gastroenterol. 2011, 48, 186-189. [CrossRef] [PubMed]

55. Bano, A.; Chaker, L.; Plompen, E.P.; Hofman, A.; Dehghan, A.; Franco, O.H.; Janssen, H.L.; Darwish Murad, S.; Peeters, R.P. Thyroid Function and the Risk of Nonalcoholic Fatty Liver Disease: The Rotterdam Study. J. Clin. Endocrinol. Metab. 2016, 101, 3204-3211. [CrossRef]

56. Van den Berg, E.H.; van Tienhoven-Wind, L.J.; Amini, M.; Schreuder, T.C.; Faber, K.N.; Blokzijl, H.; Dullaart, R.P. Higher free triiodothyronine is associated with non-alcoholic fatty liver disease in euthyroid subjects: The Lifelines Cohort Study. Metabolism 2017, 67, 62-71. [CrossRef] 
57. Manka, P.; Bechmann, L.; Best, J.; Sydor, S.; Claridge, L.C.; Coombes, J.D.; Canbay, A.; Moeller, L.; Gerken, G.; Wedemeyer, H.; et al. Low Free Triiodothyronine Is Associated with Advanced Fibrosis in Patients at High Risk for Nonalcoholic Steatohepatitis. Dig. Dis. Sci. 2019, 64, 2351-2358. [CrossRef]

58. Jaruvongvanich, V.; Sanguankeo, A.; Upala, S. Nonalcoholic fatty liver disease is not associated with thyroid hormone levels and hypothyroidism: A systematic review and meta-analysis. Eur. Thyroid J. 2017, 6, 208-215. [CrossRef]

59. He, W.; An, X.; Li, L.; Shao, X.; Li, Q.; Yao, Q.; Zhang, J.A. Relationship between hypothyroidism and non-alcoholic fatty liver disease: A systematic review and meta-analysis. Front. Endocrinol. 2017, 8, 335. [CrossRef]

60. Guo, Z.; Li, M.; Han, B.; Qi, X. Association of non-alcoholic fatty liver disease with thyroid function: A systematic review and meta-analysis. Dig. Liver Dis. 2018, 50, 1153-1162. [CrossRef]

61. Bril, F.; Kadiyala, S.; Cusi, K. Hypothyroidism in Nonalcoholic Fatty Liver Disease: Causative Factor or Innocent Bystander? Thyroid. 2019, 29, 452. [CrossRef] [PubMed]

62. Mantovani, A.; Nascimbeni, F.; Lonardo, A.; Zoppini, G.; Bonora, E.; Mantzoros, C.S.; Targher, G. Association Between Primary Hypothyroidism and Nonalcoholic Fatty Liver Disease: A Systematic Review and Meta-Analysis. Thyroid 2018, 28, 1270-1284. [CrossRef] [PubMed]

63. Zhang, J.; Sun, H.; Chen, L.; Zheng, J.; Hu, X.; Wang, S.; Chen, T. Relationship between serum TSH level with obesity and NAFLD in euthyroid subjects. J. Huazhong Univ. Sci. Technol. Med. Sci. 2012, 32, 47-52. [CrossRef] [PubMed]

64. Ittermann, T.; Haring, R.; Wallaschofski, H.; Baumeister, S.E.; Nauck, M.; Dörr, M.; Lerch, M.M.; Meyer zu Schwabedissen, H.E.; Rosskopf, D.; Völzke, H. Inverse association between serum free thyroxine levels and hepatic steatosis: Results from the Study of Health in Pomerania. Thyroid 2012, 22, 568-574. [CrossRef] [PubMed]

65. Eshraghian, A.; Dabbaghmanesh, M.H.; Eshraghian, H.; Fattahi, M.R.; Omrani, G.R. Nonalcoholic fatty liver disease in a cluster of Iranian population: Thyroid status and metabolic risk factors. Arch. Iran. Med. 2013, 16, 584-589. [PubMed]

66. Posadas-Romero, C.; Jorge-Galarza, E.; Posadas-Sánchez, R.; Acuña-Valerio, J.; Juárez-Rojas, J.G.; Kimura-Hayama, E.; Medina-Urrutia, A.; Cardoso-Saldaña, G.C. Fatty liver largely explains associations of subclinical hypothyroidism with insulin resistance, metabolic syndrome, and subclinical coronary atherosclerosis. Eur. J. Endocrinol. 2014, 171, 319-325. [CrossRef]

67. Wang, Y.F.; Zhao, J.J. The Relationship between the Broad Spectrum of Subclinical Hypothyroidism and NAFLD in Elderly Subjects. Master's Thesis, Shandong University, Jinan, China, 2014.

68. Ludwig, U.; Holzner, D.; Denzer, C.; Greinert, A.; Haenle, M.M.; Oeztuerk, S.; Koenig, W.; Boehm, B.O.; Mason, R.A.; Kratzer, W.; et al. EMIL-Study. Subclinical and clinical hypothyroidism and non-alcoholic fatty liver disease: A cross-sectional study of a random population sample aged 18 to 65 years. BMC Endocr. Disord. 2015, 15, 41. [CrossRef]

69. Lee, K.W.; Bang, K.B.; Rhee, E.J.; Kwon, H.J.; Lee, M.Y.; Cho, Y.K. Impact of hypothyroidism on the development of non-alcoholic fatty liver disease: A 4-year retrospective cohort study. Clin. Mol. Hepatol. 2015, 21, 372-378. [CrossRef]

70. Lingad-Sayas, R.C.; Montano, C.N.; Isidro, M.J.C. Prevalence of elevated TSH and its association with dyslipidemia and NAFLD among Filipino adult executive check-up patients in a tertiary hospital. Philipp. J. Intern. Med. 2017, 55, 1-8.

71. Lee, J.; Ha, J.; Jo, K.; Lim, D.J.; Lee, J.M.; Chang, S.A.; Kang, M.I.; Cha, B.Y.; Kim, M.H. Male-specific association between subclinical hypothyroidism and the risk of non-alcoholic fatty liver disease estimated by hepatic steatosis index: Korea National Health and Nutrition Examination Survey 2013 to 2015. Sci. Rep. 2018, 8, 15145. [CrossRef]

72. Escudé, A.M.; Pera, G.; Arteaga, I.; Expósito, C.; Rodríguez, L.; Torán, P.; Caballeria, L. Relationship between hypothyroidism and non-alcoholic fatty liver disease in the Spanish population. Med. Clin. 2020, 154, 1-6. [CrossRef]

73. Lonardo, A.; Nascimbeni, F.; Ballestri, S.; Fairweather, D.; Win, S.; Than, T.A.; Abdelmalek, M.F.; Suzuki, A. Sex Differences in Nonalcoholic Fatty Liver Disease: State of the Art and Identification of Research Gaps. Hepatology 2019, 70, 1457-1469. [CrossRef] [PubMed] 
74. Zhaldak, D.A.; Melekhovets, O.K.; Orlovskyi, V.F. CYP7A1 gene polymorphism and the characteristics of dyslipidemias in patients with nonalcoholic fatty liver disease concurrent with hypothyroidism. Ter. Arkh. 2017, 89, 62-65. [CrossRef] [PubMed]

75. Notariza, K.R.; Wisnu, W. The Risk of Developing Non-Alcoholic Fatty Liver Disease in Adult Patients with Subclinical Hypothyroidism Compared to Euthyroid: An Evidence-based Case Report. Acta Med. Indones. 2019, 51, 179-188. [PubMed]

76. Chaker, L.; Bianco, A.C.; Jonklaas, J.; Peeters, R.P. Hypothyroidism. Lancet 2017, 390, 1550-1562. [CrossRef]

77. Kim, M.; Kim, S.; Jung, J. Obese Subjects with Non-Alcoholic Fatty Liver Disease Have a Higher Risk of Thyroid Dysfunction. Kosin Med. J. 2019, 34, 117. [CrossRef]

78. Yang, L.; Lv, X.; Yue, F.; Wei, D.; Liu, W.; Zhang, T. Subclinical hypothyroidism and the risk of metabolic syndrome: A meta-analysis of observational studies. Endocr. Res. 2016, 41, 158-165. [CrossRef]

79. Nasr, P.; Blomdahl, J.; Kechagias, S.; Ekstedt, M. Modifiers of Liver-Related Manifestation in the Course of NAFLD. Curr. Pharm. Des. 2020, 26, 1062-1078. [CrossRef]

80. Allelein, S.; Schott, M. Schilddrüsenfunktionsstörungen [Thyroid dysfunction]. MMW Fortschr. Med. 2016, 158, 45-52. [CrossRef]

81. Bianco, A.C. We All Know We Need Them, We Hope They Are Coming, But When? Thyroid 2020, 30, 791-793. [CrossRef]

82. Ortiga-Carvalho, T.M.; Chiamolera, M.I.; Pazos-Moura, C.C.; Wondisford, F.E. Hypothalamus-PituitaryThyroid Axis. Compr. Physiol. 2016, 6, 1387-1428. [CrossRef] [PubMed]

83. Mendoza, A.; Hollenberg, A.N. New insights into thyroid hormone action. Pharmacol. Ther. 2017, 173, 135-145. [CrossRef] [PubMed]

84. Ritter, M.J.; Amano, I.; Hollenberg, A.N. Thyroid Hormone Signaling and the Liver. Hepatology 2020. [CrossRef]

85. Flamant, F.; Cheng, S.Y.; Hollenberg, A.N.; Moeller, L.C.; Samarut, J.; Wondisford, F.E.; Yen, P.M.; Refetoff, S. Thyroid Hormone Signaling Pathways: Time for a More Precise Nomenclature. Endocrinology 2017, 158, 2052-2057. [CrossRef]

86. Hönes, G.S.; Rakov, H.; Logan, J.; Liao, X.H.; Werbenko, E.; Pollard, A.S.; Præstholm, S.M.; Siersbæk, M.S.; Rijntjes, E.; Gassen, J.; et al. Noncanonical thyroid hormone signaling mediates cardiometabolic effects in vivo. Proc. Natl. Acad. Sci. USA 2017, 114, E11323-E11332. [CrossRef] [PubMed]

87. Liang, N.; Jakobsson, T.; Fan, R.; Treuter, E. The Nuclear Receptor-Co-repressor Complex in Control of Liver Metabolism and Disease. Front. Endocrinol. 2019, 10, 411. [CrossRef]

88. Krause, C.; Grohs, M.; El Gammal, A.T.; Wolter, S.; Lehnert, H.; Mann, O.; Mittag, J.; Kirchner, H. Reduced expression of thyroid hormone receptor $\beta$ in human nonalcoholic steatohepatitis. Endocr. Connect. 2018, 7, 1448-1456. [CrossRef]

89. Briet, C.; Suteau-Courant, V.; Munier, M.; Rodien, P. Thyrotropin receptor, still much to be learned from the patients. Best Pract. Res. Clin. Endocrinol. Metab. 2018, 32, 155-164. [CrossRef]

90. Cioffi, F.; Lanni, A.; Goglia, F. Thyroid hormones, mitochondrial bioenergetics and lipid handling. Curr. Opin. Endocrinol. Diabetes Obes. 2010, 17, 402-407. [CrossRef]

91. Perra, A.; Plateroti, M.; Columbano, A. T3/TRs axis in hepatocellular carcinoma: New concepts for an old pair. Endocr. Relat. Cancer 2016, 23, R353-R369. [CrossRef]

92. Lin, H.Y.; Tang, H.Y.; Leinung, M.; Mousa, S.A.; Hercbergs, A.; Davis, P.J. Action of reverse T3 on cancer cells. Endocr. Res. 2019, 3, 1-5. [CrossRef] [PubMed]

93. Fonseca, T.L.; Fernandes, G.W.; McAninch, E.A.; Bocco, B.M.; Abdalla, S.M.; Ribeiro, M.O.; Mohácsik, P.; Fekete, C.; Li, D.; Xing, X.; et al. Perinatal deiodinase 2 expression in hepatocytes defines epigenetic susceptibility to liver steatosis and obesity. Proc. Natl. Acad. Sci. USA 2015, 112, 14018-14023. [CrossRef]

94. Luongo, C.; Dentice, M.; Salvatore, D. Deiodinases and their intricate role in thyroid hormone homeostasis. Nat. Rev. Endocrinol. 2019, 15, 479-488. [CrossRef] [PubMed]

95. Gionfra, F.; De Vito, P.; Pallottini, V.; Lin, H.Y.; Davis, P.J.; Pedersen, J.Z.; Incerpi, S. The Role of Thyroid Hormones in Hepatocyte Proliferation and Liver Cancer. Front. Endocrinol. 2019, 10, 532. [CrossRef] [PubMed]

96. Dentice, M.; Marsili, A.; Ambrosio, R.; Guardiola, O.; Sibilio, A.; Paik, J.H.; Minchiotti, G.; DePinho, R.A.; Fenzi, G.; Larsen, P.R.; et al. FoxO3/type 2 deiodinase pathway is required for normal mouse myogenesis and muscle regeneration. J. Clin. Investig. 2010, 120, 4021-4030. [CrossRef] 
97. Goemann, I.M.; Romitti, M.; Meyer, E.; Wajner, S.M.; Maia, A.L. Role of thyroid hormones in the neoplastic process: An overview. Endocr. Relat. Cancer 2017, 24, R367-R385. [CrossRef]

98. Kester, M.H.; Toussaint, M.J.; Punt, C.A.; Matondo, R.; Aarnio, A.M.; Darras, V.M.; Everts, M.E.; de Bruin, A.; Visser, T.J. Large induction of type III deiodinase expression after partial hepatectomy in the regenerating mouse and rat liver. Endocrinology 2009, 150, 540-545. [CrossRef]

99. De Pergola, G.; Ciampolillo, A.; Paolotti, S.; Trerotoli, P.; Giorgino, R. Free triiodothyronine and thyroid stimulating hormone are directly associated with waist circumference, independently of insulin resistance, metabolic parameters and blood pressure in overweight and obese women. Clin. Endocrinol. 2007, 67, 265-269. [CrossRef]

100. Bruck, R.; Weiss, S.; Traister, A.; Zvibel, I.; Aeed, H.; Halpern, Z.; Oren, R. Induced hypothyroidism accelerates the regression of liver fibrosis in rats. J. Gastroenterol. Hepatol. 2007, 22, 2189-2194. [CrossRef]

101. Abdalla, S.M.; Bianco, A.C. Defending plasma T3 is a biological priority. Clin. Endocrinol. 2014, 81, 633-641. [CrossRef]

102. Gilgenkrantz,H.; Collin de l'Hortet, A. Understanding Liver Regeneration: From Mechanisms to Regenerative Medicine. Am. J. Pathol. 2018, 188, 1316-1327. [CrossRef] [PubMed]

103. Elbers, L.P.; Kastelein, J.J.; Sjouke, B. Thyroid Hormone Mimetics: The Past, Current Status and Future Challenges. Curr. Atheroscler. Rep. 2016, 18, 14. [CrossRef] [PubMed]

104. Bohinc, B.N.; Michelotti, G.; Xie, G.; Pang, H.; Suzuki, A.; Guy, C.D.; Piercy, D.; Kruger, L.; Swiderska-Syn, M.; Machado, M.; et al. Repair-related activation of hedgehog signaling in stromal cells promotes intrahepatic hypothyroidism. Endocrinology 2014, 155, 4591-4601. [CrossRef] [PubMed]

105. Li, Q.L.; Yamamoto, N.; Inoue, A.; Morisawa, S. Fatty acyl-CoAs are potent inhibitors of the nuclear thyroid hormone receptor in vitro. J. Biochem. 1990, 107, 699-702. [CrossRef] [PubMed]

106. Yao, X.; Hou, S.; Zhang, D.; Xia, H.; Wang, Y.C.; Jiang, J.; Yin, H.; Ying, H. Regulation of fatty acid composition and lipid storage by thyroid hormone in mouse liver. Cell Biosci. 2014, 4, 38. [CrossRef]

107. Damiano, F.; Rochira, A.; Gnoni, A.; Siculella, L. Action of Thyroid Hormones, T3 and T2, on Hepatic Fatty Acids: Differences in Metabolic Effects and Molecular Mechanisms. Int. J. Mol. Sci. 2017, 18, 744. [CrossRef]

108. Kechagias, S.; Nasr, P.; Blomdahl, J.; Ekstedt, M. Established and emerging factors affecting the progression of nonalcoholic fatty liver disease. Metabolism 2020, 154183. [CrossRef]

109. Teixeira, P.; Dos Santos, P.B.; Pazos-Moura, C.C. The role of thyroid hormone in metabolism and metabolic syndrome. Ther. Adv. Endocrinol. Metab. 2020, 11, 2042018820917869. [CrossRef]

110. Coppola, M.; Cioffi, F.; Moreno, M.; Goglia, F.; Silvestri, E. 3,5-diiodo-L-thyronine: A Possible Pharmacological Agent? Curr. Drug Deliv. 2016, 13, 330-338. [CrossRef]

111. Czech, M.P. Mechanisms of insulin resistance related to white, beige, and brown adipocytes. Mol. Metab. 2020, 34, 27-42. [CrossRef]

112. Sinha, R.A.; Singh, B.K.; Yen, P.M. Direct effects of thyroid hormones on hepatic lipid metabolism. Nat. Rev. Endocrinol. 2018, 14, 259-269. [CrossRef]

113. Grasselli, E.; Voci, A.; Demori, I.; Vecchione, G.; Compalati, A.D.; Gallo, G.; Goglia, F.; De Matteis, R.; Silvestri, E.; Vergani, L. Triglyceride Mobilization from Lipid Droplets Sustains the Anti-Steatotic Action of Iodothyronines in Cultured Rat Hepatocytes. Front. Physiol. 2016, 6, 418. [CrossRef] [PubMed]

114. Musso, G.; Cassader, M.; Paschetta, E.; Gambino, R. Bioactive Lipid Species and Metabolic Pathways in Progression and Resolution of Nonalcoholic Steatohepatitis. Gastroenterology 2018, 155, 282-302. [CrossRef] [PubMed]

115. Pandrc, M.S.; Ristić, A.; Kostovski, V.; Stanković, M.; Antić, V.; Milin-Lazović, J.; Ćirić, J. The Effect of Early Substitution of Subclinical Hypothyroidism on Biochemical Blood Parameters and the Quality of Life. J. Med. Biochem. 2017, 36, 127-136. [CrossRef] [PubMed]

116. Efstathiadou, Z.A.; Kita, M.D.; Polyzos, S.A. Thyroid dysfunction and non-alcoholic fatty liver disease. Minerva Endocrinol. 2018, 43, 367-376. [CrossRef]

117. Wahrenberg, H.; Wennlund, A.; Arner, P. Adrenergic regulation of lipolysis in fat cells from hyperthyroid and hypothyroid patients. J. Clin. Endocrinol. Metab. 1994, 78, 898-903. [CrossRef]

118. Song, Y.; Xu, C.; Shao, S.; Liu, J.; Xing, W.; Xu, J.; Qin, C.; Li, C.; Hu, B.; Yi, S.; et al. Thyroid-stimulating hormone regulates hepatic bile acid homeostasis via SREBP-2/HNF-4 $\alpha / C Y P 7 A 1$ axis. J. Hepatol. 2015, 62, 1171-1179. [CrossRef] 
119. Duntas, L.H.; Brenta, G. Renewed Focus on the Association Between Thyroid Hormones and Lipid Metabolism. Front. Endocrinol. 2018, 9, 511. [CrossRef]

120. Jain, R.B. Associations between the levels of thyroid hormones and lipid/lipoprotein levels: Data from National Health and Nutrition Examination Survey 2007-2012. Environ. Toxicol. Pharmacol. 2017, 53, 133-144. [CrossRef]

121. Incerpi, S.; Davis, P.J.; Pedersen, J.Z.; Lanni, A. Nongenomic Actions of Thyroid Hormones. Endocrinology 2018, 259-284. [CrossRef]

122. Zhang, X.; Song, Y.; Feng, M.; Zhou, X.; Lu, Y.; Gao, L.; Yu, C.; Jiang, X.; Zhao, J. Thyroid-stimulating hormone decreases HMG-CoA reductase phosphorylation via AMP-activated protein kinase in the liver. J. Lipid Res. 2015, 56, 963-971. [CrossRef] [PubMed]

123. Wen, G.; Eder, K.; Ringseis, R. Sterol regulatory element-binding proteins are transcriptional regulators of the thyroglobulin gene in thyroid cells. Biochim. Biophys. Acta 2016, 1859, 994-1003. [CrossRef] [PubMed]

124. Martínez-Sánchez, N.; Seoane-Collazo, P.; Contreras, C.; Varela, L.; Villarroya, J.; Rial-Pensado, E.; Buqué, X.; Aurrekoetxea, I.; Delgado, T.C.; Vázquez-Martínez, R.; et al. Hypothalamic AMPK-ER Stress-JNK1 Axis Mediates the Central Actions of Thyroid Hormones on Energy Balance. Cell Metab. 2017, 26, $212-229$. [CrossRef] [PubMed]

125. Fazaeli, M.; Khoshdel, A.; Shafiepour, M.; Rohban, M. The influence of subclinical hypothyroidism on serum lipid profile, PCSK9 levels and CD36 expression on monocytes. Diabetes Metab. Syndr. 2019, 13, 312-316. [CrossRef] [PubMed]

126. Chi, H.C.; Tsai, C.Y.; Tsai, M.M.; Yeh, C.T.; Lin, K.H. Molecular functions and clinical impact of thyroid hormone-triggered autophagy in liver-related diseases. J. Biomed. Sci. 2019, 26, 24. [CrossRef] [PubMed]

127. Iwanicki, T.; Balcerzyk, A.; Niemiec, P.; Trautsolt, W.; Grzeszczak, W.; Ochalska-Tyka, A.; Krauze, J.; Nowak, T.; Żak, I. The relationship between CYP7A1 polymorphisms, coronary artery disease \& serum lipid markers. Biomark. Med. 2019, 13, 1199-1208. [CrossRef]

128. Sharma, P.; Levesque, T.; Boilard, E.; Park, E.A. Thyroid hormone status regulates the expression of secretory phospholipases. Biochem. Biophys. Res. Commun. 2014, 444, 56-62. [CrossRef]

129. Araki, O.; Ying, H.; Zhu, X.G.; Willingham, M.C.; Cheng, S.Y. Distinct dysregulation of lipid metabolism by unliganded thyroid hormone receptor isoforms. Mol. Endocrinol. 2009, 23, 308-315. [CrossRef]

130. Jornayvaz, F.R.; Lee, H.Y.; Jurczak, M.J.; Alves, T.C.; Guebre-Egziabher, F.; Guigni, B.A.; Zhang, D.; Samuel, V.T.; Silva, J.E.; Shulman, G.I. Thyroid hormone receptor- $\alpha$ gene knockout mice are protected from diet-induced hepatic insulin resistance. Endocrinology 2012, 153, 583-591. [CrossRef]

131. Iannucci, L.F.; Cioffi, F.; Senese, R.; Goglia, F.; Lanni, A.; Yen, P.M.; Sinha, R.A. Metabolomic analysis shows differential hepatic effects of T2 and T3 in rats after short-term feeding with high fat diet. Sci. Rep. 2017, 7, 2023. [CrossRef]

132. Beukhof, C.M.; Massolt, E.T.; Visser, T.J.; Korevaar, T.; Medici, M.; de Herder, W.W.; Roeters van Lennep, J.E.; Mulder, M.T.; de Rijke, Y.B.; Reiners, C.; et al. Effects of Thyrotropin on Peripheral Thyroid Hormone Metabolism and Serum Lipids. Thyroid 2018, 28, 168-174. [CrossRef] [PubMed]

133. Lopez, D.; Socarrás, J.F.A.; Bedi, M.; Ness, G.C. Activation of the hepatic LDL receptor promoter by thyroid hormone. Biochim. Biophys. Acta 2007, 1771, 1216-1225. [CrossRef] [PubMed]

134. Yap, C.S.; Sinha, R.A.; Ota, S.; Katsuki, M.; Yen, P.M. Thyroid hormone negatively regulates CDX2 and SOAT2 mRNA expression via induction of miRNA-181d in hepatic cells. Biochem. Biophys. Res. Commun. 2013, 440, 635-639. [CrossRef] [PubMed]

135. Zhang, L.; Wu, K.; Bo, T.; Zhou, L.; Gao, L.; Zhou, X.; Chen, W. Integrated microRNA and proteome analysis reveal a regulatory module in hepatic lipid metabolism disorders in mice with subclinical hypothyroidism. Exp. Ther. Med. 2020, 19, 897-906. [CrossRef] [PubMed]

136. Sinha, R.A.; Yen, P.M. Thyroid hormone-mediated autophagy and mitochondrial turnover in NAFLD. Cell Biosci. 2016, 6, 46. [CrossRef]

137. Ward, C.; Martinez-Lopez, N.; Otten, E.G.; Carroll, B.; Maetzel, D.; Singh, R.; Sarkar, S.; Korolchuk, V.I. Autophagy, lipophagy and lysosomal lipid storage disorders. Biochim. Biophys. Acta 2016, 1861, 269-284. [CrossRef]

138. Krotkiewski, M. Thyroid hormones and treatment of obesity. Int. J. Obes. Relat. Metab. Disord. 2000, 24, S116-S119. [CrossRef] 
139. Karbownik-Lewińska, M.; Stępniak, J.; Żurawska, A.; Lewiński, A. Less Favorable Lipid Profile and Higher Prevalence of Thyroid Antibodies in Women of Reproductive Age with High-Normal TSH-Retrospective Study. Int. J. Environ. Res. Public Health 2020, 17, 2122. [CrossRef]

140. Kumar, R.; Priyadarshi, R.N.; Anand, U. Non-alcoholic Fatty Liver Disease: Growing Burden, Adverse Outcomes and Associations. J. Clin. Transl. Hepatol. 2020, 8, 76-86. [CrossRef]

141. Chen, C.; Xie, Z.; Shen, Y.; Xia, S.F. The Roles of Thyroid and Thyroid Hormone in Pancreas: Physiology and Pathology. Int. J. Endocrinol. 2018, 2018, 2861034. [CrossRef]

142. Geisler, C.E.; Renquist, B.J. Hepatic lipid accumulation: Cause and consequence of dysregulated glucoregulatory hormones. J. Endocrinol. 2017, 234, R1-R21. [CrossRef] [PubMed]

143. Pearce, E.N. Update in lipid alterations in subclinical hypothyroidism. J. Clin. Endocrinol. Metab. 2012, 97, 326-333. [CrossRef] [PubMed]

144. Kowalska, I.; Borawski, J.; Nikołajuk, A.; Budlewski, T.; Otziomek, E.; Górska, M.; Strączkowski, M. Insulin sensitivity, plasma adiponectin and sICAM-1 concentrations in patients with subclinical hypothyroidism: Response to levothyroxine therapy. Endocrine 2011, 40, 95-101. [CrossRef] [PubMed]

145. Velarde-Ruiz Velasco, J.A.; García-Jiménez, E.S.; García-Zermeño, K.R.; Morel-Cerda, E.C.; Aldana-Ledesma, J.M.; Castro-Narro, G.E.; Cerpa-Cruz, S.; Tapia-Calderón, D.K.; Mercado-Jauregui, L.A.; Contreras-Omaña, R. Extrahepatic complications of non-alcoholic fatty liver disease: Its impact beyond the liver. Complicaciones extrahepáticas de la enfermedad por hígado graso no alcohólico: Impacto más allá del hígado. Rev. Gastroenterol. Mex. 2019, 84, 472-481. [CrossRef] [PubMed]

146. Cai, J.; Zhang, X.J.; Li, H. The Role of Innate Immune Cells in Nonalcoholic Steatohepatitis. Hepatology 2019, 70, 1026-1037. [CrossRef] [PubMed]

147. Moro, L. Mitochondria at the Crossroads of Physiology and Pathology. J. Clin. Med. 2020, 9, 1971. [CrossRef]

148. Mancini, A.; Di Segni, C.; Raimondo, S.; Olivieri, G.; Silvestrini, A.; Meucci, E.; Currò, D. Thyroid Hormones, Oxidative Stress, and Inflammation. Mediat. Inflamm. 2016, 2016, 6757154. [CrossRef]

149. Liu, X.; Green, R.M. Endoplasmic reticulum stress and liver diseases. Liver Res. 2019, 3, 55-64. [CrossRef]

150. Rius-Pérez, S.; Torres-Cuevas, I.; Millán, I.; Ortega, Á.L.; Pérez, S. PGC-1 $\alpha$, Inflammation, and Oxidative Stress: An Integrative View in Metabolism. Oxid. Med. Cell. Longev. 2020, 2020, 1452696. [CrossRef]

151. Lanni, A.; Moreno, M.; Goglia, F. Mitochondrial Actions of Thyroid Hormone. Compr. Physiol. 2016, 6, 1591-1607. [CrossRef]

152. Yamauchi, M.; Kambe, F.; Cao, X.; Lu, X.; Kozaki, Y.; Oiso, Y.; Seo, H. Thyroid hormone activates adenosine $5^{\prime}$-monophosphate-activated protein kinase via intracellular calcium mobilization and activation of calcium/calmodulin-dependent protein kinase kinase-beta. Mol. Endocrinol. 2008, 22, 893-903. [CrossRef] [PubMed]

153. Górska, M.; Dobrzyń, A.; Langfort, J.; Górski, J. Effect of hypothyreosis on the content of ceramides in rat tissues. J. Physiol. Pharmacol. 2003, 54, 89-97. [PubMed]

154. Öztürk, Ü.; Vural, P.; Özderya, A.; Karadağ, B.; Doğru-Abbasoğlu, S.; Uysal, M. Oxidative stress parameters in serum and low density lipoproteins of Hashimoto's thyroiditis patients with subclinical and overt hypothyroidism. Int. Immunopharmacol. 2012, 14, 349-352. [CrossRef] [PubMed]

155. Manka, P.; Coombes, J.D.; Boosman, R.; Gauthier, K.; Papa, S.; Syn, W.K. Thyroid hormone in the regulation of hepatocellular carcinoma and its microenvironment. Cancer Lett. 2018, 419, 175-186. [CrossRef] [PubMed]

156. Higashi, T.; Friedman, S.L.; Hoshida, Y. Hepatic stellate cells as key target in liver fibrosis. Adv. Drug Deliv. Rev. 2017, 121, 27-42. [CrossRef]

157. Giammanco, M.; Di Liegro, C.M.; Schiera, G.; Di Liegro, I. Genomic and Non-Genomic Mechanisms of Action of Thyroid Hormones and Their Catabolite 3,5-Diiodo-L-Thyronine in Mammals. Int. J. Mol. Sci. 2020, 21, 4140. [CrossRef]

158. Marchisello, S.; Di Pino, A.; Scicali, R.; Urbano, F.; Piro, S.; Purrello, F.; Rabuazzo, A.M. Pathophysiological, Molecular and Therapeutic Issues of Nonalcoholic Fatty Liver Disease: An Overview. Int. J. Mol. Sci. 2019, 20, 1948. [CrossRef]

159. Gong, N.; Gao, C.; Chen, X.; Wang, Y.; Tian, L. Adipokine expression and endothelial function in subclinical hypothyroidism rats. Endocr. Connect. 2018, 7, 295-304. [CrossRef]

160. Gamberi, T.; Magherini, F.; Modesti, A.; Fiaschi, T. Adiponectin Signaling Pathways in Liver Diseases. Biomedicines 2018, 6, 52. [CrossRef] 
161. Nier, A.; Huber, Y.; Labenz, C.; Michel, M.; Bergheim, I.; Schattenberg, J.M. Adipokines and Endotoxemia Correlate with Hepatic Steatosis in Non-Alcoholic Fatty Liver Disease (NAFLD). Nutrients 2020, 12, 699. [CrossRef]

162. Izquierdo, A.G.; Crujeiras, A.B.; Casanueva, F.F.; Carreira, M.C. Leptin, Obesity, and Leptin Resistance: Where Are We 25 Years Later? Nutrients 2019, 11, 2704. [CrossRef]

163. Iacobellis, G.; Ribaudo, M.C.; Zappaterreno, A.; Iannucci, C.V.; Leonetti, F. Relationship of thyroid function with body mass index, leptin, insulin sensitivity and adiponectin in euthyroid obese women. Clin. Endocrinol. 2005, 62, 487-491. [CrossRef]

164. Johannsen, K.; Flechtner-Mors, M.; Kratzer, W.; Koenig, W.; Boehm, B.O.; Schmidberger, J.; EMIL-Study Group. Association Between Visfatin and Hepatic Steatosis in the General Population During Long-Term Follow-Up. Horm. Metab. Res. 2019, 51, 602-607. [CrossRef] [PubMed]

165. Elkabany, Z.A.; Hamza, R.T.; Ismail, E.; Elsharkawy, A.; Yosry, A.; Musa, S.; Khalaf, M.A.; Elgawesh, R.M.; Esmat, G. Serum visfatin level as a noninvasive marker for nonalcoholic fatty liver disease in children and adolescents with obesity: Relation to transient elastography with controlled attenuation parameter. Eur. J. Gastroenterol. Hepatol. 2019. [CrossRef] [PubMed]

166. Tezze, C.; Romanello, V.; Sandri, M. FGF21 as Modulator of Metabolism in Health and Disease. Front. Physiol. 2019, 10, 419. [CrossRef] [PubMed]

167. Tucker, B.; Li, H.; Long, X.; Rye, K.A.; Ong, K.L. Fibroblast growth factor 21 in non-alcoholic fatty liver disease. Metabolism 2019, 101, 153994. [CrossRef]

168. Lee, Y.; Park, Y.J.; Ahn, H.Y.; Lim, J.A.; Park, K.U.; Choi, S.H.; Park, D.J.; Oh, B.C.; Jang, H.C.; Yi, K.H. Plasma FGF21 levels are increased in patients with hypothyroidism independently of lipid profile. Endocr. J. 2013, 60, 977-983. [CrossRef]

169. Adams, A.C.; Astapova, I.; Fisher, F.M.; Badman, M.K.; Kurgansky, K.E.; Flier, J.S.; Hollenberg, A.N.; Maratos-Flier, E. Thyroid hormone regulates hepatic expression of fibroblast growth factor 21 in a PPARalpha-dependent manner. J. Biol. Chem. 2010, 285, 14078-14082. [CrossRef]

170. Delitala, A.P.; Steri, M.; Pilia, M.G.; Dei, M.; Lai, S.; Delitala, G.; Schlessinger, D.; Cucca, F. Menopause modulates the association between thyrotropin levels and lipid parameters: The SardiNIA study. Maturitas 2016, 92, 30-34. [CrossRef]

171. Brenta, G.; Berg, G.; Miksztowicz, V.; Lopez, G.; Lucero, D.; Faingold, C.; Murakami, M.; Machima, T.; Nakajima, K.; Schreier, L. Atherogenic Lipoproteins in Subclinical Hypothyroidism and Their Relationship with Hepatic Lipase Activity: Response to Replacement Treatment with Levothyroxine. Thyroid 2016, 26, 365-372. [CrossRef]

172. Jonklass, J.; Bianco, A.C.; Bauer, A.J.; Burman, K.D.; Cappola, A.R.; Celi, F.S.; Cooper, D.S.; Kim, B.W.; Peeters, R.P.; Rosenthal, M.S.; et al. Guidelines for the treatment of hypothyroidism. Thyroid 2014, 24, 1670-1751. [CrossRef]

173. Garber, J.R.; Cobin, R.H.; Gharib, H. Clinical practice guidelines for hypothyroidism in adults: Cosponsored by the American Association of Clinical Endocrinologists and the American Thyroid Association. Endocr. Pract. 2012, 18, 988-1028. [CrossRef] [PubMed]

174. Liu, L.; Yu, Y.; Zhao, M.; Zheng, D.; Zhang, X.; Guan, Q.; Xu, C.; Gao, L.; Zhao, J.; Zhang, H. Benefits of levothyroxine replacement therapy on nonalcoholic fatty liver disease in subclinical hypothyroidism patients. Int. J. Endocrinol. 2017, 2017. [CrossRef] [PubMed]

175. Bruinstroop, E.; Dalan, R.; Yang, C.; Bee, Y.M.; Chandran, K.; Cho, L.W.; Soh, S.B.; Teo, E.K.; Toh, S.A.; Leow, M.K.S.; et al. Low dose levothyroxine reduces intrahepatic lipid content in patients with type 2 diabetes mellitus and NAFLD. J. Clin. Endocrinol. Metab. 2018, 103, 2698-2706. [CrossRef] [PubMed]

176. Chi, H.C.; Chen, C.Y.; Tsai, M.M.; Tsai, C.Y.; Lin, K.H. Molecular functions of thyroid hormones and their clinical significance in liver-related diseases. Biomed. Res. Int. 2013, 2013. [CrossRef]

177. Senese, R.; Cioffi, F.; de Lange, P.; Leanza, C.; Iannucci, L.F.; Silvestri, E.; Moreno, M.; Lombardi, A.; Goglia, F.; Lanni, A. Both 3,5-diiodo-L-thyronine and 3,5,3'-triiodo-L-thyronine prevent short-term hepatic lipid accumulation via distinct mechanisms in rats being fed a high-fat diet. Front. Physiol. 2017, 8, 706. [CrossRef]

178. Kowalik, M.A.; Columbano, A.; Perra, A. Thyroid hormones, thyromimetics and their metabolites in the treatment of liver disease. Front. Endocinol. 2018, 9, 382. [CrossRef] 
179. Perra, A.; Simbula, G.; Simbula, M.; Pibiri, M.; Kowalik, M.A.; Sulas, P.; Cocco, M.T.; Ledda-Columbano, G.M.; Columbano, A. Thyroid hormone (T3) and TR $\beta$ agonist GC-1 inhibit/reverse nonalcoholic fatty liver in rats. FASEB J. 2008, 22, 2981-2989. [CrossRef]

180. Levy, D.E.; Lee, C.K. What does Stat3 do? J. Clint. Investig. 2002, 109, 1143-1148. [CrossRef]

181. Cable, E.E.; Finn, P.D.; Stebbins, J.W.; Hou, J.; Ito, B.R.; van Poelje, P.D.; Linemeyer, D.L.; Erion, M.D. Reduction of hepatic steatosis in rats and mice after treatment with a liver-targeted thyroid hormone receptor agonist. Hepayology 2009, 49, 407-417. [CrossRef]

182. Sinha, R.A.; Bruinstroop, E.; Singh, B.K.; Yen, P.M. Nonalcoholic fatty liver disease and hypercholesterolemia: Role of thyroid hormones, metabolites and agonists. Thyroid 2019, 29, 1173-1191. [CrossRef] [PubMed]

183. Alvarez-Crespo, M.; Csikasz, R.I.; Martínez-Sánchez, N.; Diéguez, C.; Cannon, B.; Nedergaard, J.; López, M. Essential role of UCP1 modulating the central effects of thyroid hormones on energy balance. Mol. Metab. 2016, 5, 271-282. [CrossRef] [PubMed]

184. Klein, I.; Ojamaa, K. Thyroid hormone and the cardiovascular system. N. Engl. J. Med. 2001, 344, 501-509. [CrossRef] [PubMed]

185. Arrojo, E.D.R.; Fonseca, T.L.; Werneck-de-Castro, J.P.; Bianco, A.C. Role of type 2 iodothyronine deiodinase (D2) in the control of thyroid hormone signaling. Biochim. Biophys. Acta 2013, 1830, 3956-3964. [CrossRef] [PubMed]

186. Orozco, A.; Navarrete-Ramírez, P.; Olvera, A.; García, G.C. 3,5-Diiodothyronine (T2) is on a role. A new hormone in search of recognition. Gen. Comp. Endocrinol. 2014, 203, 174-180. [CrossRef] [PubMed]

187. Grasselli, E.; Voci, A.; Canesi, L.; De Matteis, R.; Goglia, F.; Cioffi, F.; Fugassa, E.; Gallo, G.; Vergani, L. Direct effects of iodothyronines on excess fat storage in rat hepatocytes. J. Hepatol. 2011, 54, 1230-1236. [CrossRef]

188. Jonas, W.; Lietzow, J.; Wohlgemuth, F.; Hoefig, C.S.; Wiedmer, P.; Schweizer, U.; Köhrle, J.; Schürmann, A. 3,5-Diiodo-L-thyronine (3,5-t2) exerts thyromimetic effects on hypothalamus-pituitary-thyroid axis, body composition, and energy metabolism in male diet-induced obese mice. Endocrinology 2015, 156, 389-399. [CrossRef]

189. Cioffi, F.; Zambad, S.P.; Chhipa, L.; Senese, R.; Busiello, R.A.; Tuli, D.; Munshi, S.; Moreno, M.; Lombardi, A.; Gupta, R.C.; et al. TRC150094, a novel functional analog of iodothyronines, reduces adiposity by increasing energy expenditure and fatty acid oxidation in rats receiving a high-fat diet. FASEB J. 2010, 24, 3451-3461. [CrossRef]

190. Da Silva Teixeira, S.; Filgueira, C.; Sieglaff, D.H.; Benod, C.; Villagomez, R.; Minze, L.J.; Zhang, A.; Webb, P.; Nunes, M.T. 3,5-diiodothyronine (3,5-T2) reduces blood glucose independently of insulin sensitization in obese mice. Acta Physiol. 2017, 220, 238-250. [CrossRef]

191. Zucchi, R.; Chiellini, G.; Scanlan, T.S.; Grandy, D.K. Trace amine-associated receptors and their ligands. Br. J. Pharmacol. 2006, 149, 967-978. [CrossRef]

192. Lombardi, R.; Onali, S.; Thorburn, D.; Davidson, B.R.; Gurusamy, K.S.; Tsochatzis, E. Pharmacological interventions for non-alcohol related fatty liver disease (NAFLD): An attempted network meta-analysis. Cochrane Database Syst. Rev. 2017, 3, CD011640. [CrossRef] [PubMed]

193. Ghelardoni, S.; Chiellini, G.; Frascarelli, S.; Saba, A.; Zucchi, R. Uptake and metabolic effects of 3-iodothyronamine in hepatocytes. J. Endocrinol. 2014, 221, 101-110. [CrossRef] [PubMed]

194. Vilà-Brau, A.; De Sousa-Coelho, A.L.; Mayordomo, C.; Haro, D.; Marrero, P.F. Human HMGCS2 regulates mitochondrial fatty acid oxidation and FGF2 expression in HepG2 cell line. J. Biol. Chem. 2011, 286, 20423-20430. [CrossRef]

195. Haviland, J.A.; Reiland, H.; Butz, D.E.; Tonelli, M.; Porter, W.P.; Zucchi, R.; Scanlan, T.S.; Chiellini, G.; Assadi-Porter, F.M. NMR-based metabolomics and breath studies show lipid and protein catabolism during low dose chronic T(1)AM treatment. Obesity 2013, 21, 2538-2544. [CrossRef] [PubMed]

196. Assadi-Porter, F.M.; Reiland, H.; Sabatini, M.; Lorenzini, L.; Carnicelli, V.; Rogowski, M.; Alpergin, E.S.S.; Tonelli, M.; Ghelardoni, S.; Saba, A.; et al. Metabolic Reprogramming by 3-Iodothyronamine (T1AM): A New Perspective to Reverse Obesity through Co-Regulation of Sirtuin 4 and 6 Expression. Int. J. Mol. Sci. 2018, 19, 1535. [CrossRef]

197. Ayuob, N.N.; Abdel-Hamid, A.A.H.M.; Helal, G.M.M.; Mubarak, W.A. Thymoquinone reverses nonalcoholic fatty liver disease (NAFLD) associated with experimental hypothyroidism. Rom. J. Morphol. Embryol. 2019, $60,479-486$. 
198. Khader, M.; Eckl, P.M. Thymoquinone: An emerging natural drug with a wide range of medical applications. Iran. J. Basic Med. Sci. 2014, 17, 950-957.

199. Mak, K.M.; Chen, L.L.; Lee, T.F. Codistribution of collagen type IV and laminin in liver fibrosis of elderly cadavers: Immune-histochemical marker of perisinusoidal basement membrane formation. Anat. Rec. 2013, 296, 953-964. [CrossRef]

200. Luo, F.; Ishigami, M.; Achiwa, K.; Ishizu, Y.; Juzuya, T.; Honda, T.; Hayashi, K.; Ishikawa, T.; Katano, Y.; Goto, H. Raloxifene ameliorates liver fibrosis of nonalcoholic steatohepatitis induced by choline-deficient high-fat diet in ovariectomized mice. Dig. Dis. Sci. 2015, 60, 2730-2739. [CrossRef]

201. Tacke, F. Targeting hepatic macrophages to treat liver diseases. J. Hepatol. 2017, 66, 1300-1312. [CrossRef]

202. Subudhi, U.; Chainy, G.B. Expression of hepatic antioxidant genes in L-thyroxine-induced hyperthyroid rats: Regulation by vitamin E and curcumin. Chem. Biol. Interact 2010, 183, 3014-3316. [CrossRef] [PubMed]

203. Tabassum, H.; Ahmad, A.; Ahmad, I.Z. Nigella sativa L. and its bioactive constituents as hepatoprotectant: A review. Curr. Pharm. Biotechnol. 2018, 19, 43-67. [CrossRef]

204. Vatner, D.F.; Weismann, D.; Beddow, S.A.; Kumashiro, N.; Erion, D.M.; Liao, X.H.; Grover, G.J.; Webb, P.; Phillips, K.J.; Weiss, R.E.; et al. Thyroid hormone receptor- $\beta$ agonists prevent hepatic steatosis in fat-fed rats but impair insulin sensitivity via discrete pathways. Am. J. Physiol. Endocrinol. Metab. 2013, 305, 89-100. [CrossRef] [PubMed]

205. Lammel Lindemann, J.; Webb, P. Sobetirome: The past, present and questions about the future. Expert. Opin. Ther. Targets 2016, 20, 145-149. [CrossRef]

206. Kelly, M.J.; Pietranico-Cole, S.; Larigan, J.D. Discovery of 2-[3,5-dichloro-4-(5-isopropyl-6-oxo-1,6dihydropyridine-3-yloxy) phenyl]-3,5-dioxo-2,3,4,5-tetrahydro[1,2,3]triazine-6-carbonitrile (MGL-3196), a highly selective thyroid hormone receptor $\beta$ agonist in clinical trials for the treatment of dyslipidemia. J. Med. Chem. 2014, 57, 3912-3923. [CrossRef] [PubMed]

207. Harrison, S.A.; Bashir, M.R.; Guy, C.D.; Zhou, R.; Moylan, C.A.; Frias, J.P.; Alkhouri, N.; Bansal, M.B.; Baum, S.; Neuschwander-Tetri, B.A.; et al. Resmetirom (MGL-3196) for the treatment of non-alcoholic steatohepatitis: A multicenter, randomized, double-blind, placebo-controlled, phase 2 trail. Lancet 2019, 394, 2012-2024. [CrossRef]

208. Taub, R.; Chiang, E.; Chabot-Blanchet, M. Lipid lowering in healthy volunteers treated with multiple doses of MGL-3196, a liver-targeted hormone receptor- $\beta$ agonist. Atherosclerosis 2013, 230, 373-380. [CrossRef]

209. Brunt, E.M.; Kleiner, D.E.; Wilson, L.A.; Sanyal, A.J.; Neuschwander-Tetri, B.A. Improvements in histologic features and diagnosis associated with improvement in fibrosis in nonalcoholic steatohepatitis: Results from the Nonalcoholic Steatohepatitis Clinical Research Network treatment trials. Hepatology 2019, 70, 522-531. [CrossRef]

210. Tsimikas, S. A test in context: Lipoprotein(a): Diagnosis, prognosis, controversies, and emerging therapies. J. Am. Coll. Cardiol. 2017, 69, 692-711. [CrossRef]

211. Loomba, R.; Neutel, J.; Bernard, D.; Severance, R.; Mohseni, R.; Dao, M.; Saini, S.; Margaritescu, C.; Homer, K.; Tran, B.; et al. VK2809, a novel liver-directed thyroid receptor beta agonist, significantly reduces liver fat in patients with non-alcoholic liver disease: A phase 2 randomized, placebo-controlled trial. Hepatology 2018, $68,1447 \mathrm{~A}$.

212. Finan, B.; Clemmensen, C.; Zhu, Z.; Stemmer, K.; Gauthier, K.; Müller, L.; de Angelis, M.; Moreth, K.; Neff, F.; Perez-Tilve, D.; et al. Chemical hybridization of glucagon and thyroid hormone optimizes therapeutic impact for metabolic disease. Cell 2016, 26, 1422-1430. [CrossRef] [PubMed]

(C) 2020 by the authors. Licensee MDPI, Basel, Switzerland. This article is an open access article distributed under the terms and conditions of the Creative Commons Attribution (CC BY) license (http://creativecommons.org/licenses/by/4.0/). 